\title{
The Effects of Thailand's Great Flood of 2011 on River Sediment Discharge in the Upper Chao Phraya River Basin, Thailand
}

\author{
Butsawan BIDORN ${ }^{1}$, Seree CHANYOTHA ${ }^{2}$, Stephen A. KISH ${ }^{3}$, \\ Joseph F. DONOGHUE ${ }^{4}$, Komkrit BIDORN ${ }^{5}$, Ruetaitip MAMA ${ }^{6}$
}

\footnotetext{
${ }^{1}$ Ph.D. Student, Dept. of Earth, Ocean and Atmospheric Science, Florida State University, Tallahassee, FL, 32304, USA, Email: bb11x@my.fsu.edu

2 Assoc. Prof., Dept. of Water Resources Engineering, Chulalongkorn University, Bangkok, 10330, THAILAND, Email: seree.c@chula.ac.th

3 Assoc. Prof., Dept. of Earth, Ocean and Atmospheric Science, Florida State University, Tallahassee, FL, 32304, USA, Email: Skish@ fsu.edu

4 Assoc. Prof., Department of Physics, University of Central Florida, Orlando, FL, 32306, USA, Email: Joseph.Donoghue@ucf.edu

${ }^{5}$ Researcher, Dept. of Water Resources Engineering, Chulalongkorn University, Bangkok, 10330, THAILAND, Email: b_komkrit@yahoo.com

${ }^{6}$ Hydrologist, Royal Irrigation Department, Bangkok, 10300, THAILAND, Email: bluewater_june@hotmail.com
} 


\begin{abstract}
Severe flooding that occurred during the 2011 monsoon season in Thailand was the heaviest flooding in the past 50 years. The rainfall over the northern part of Thailand, especially during July-August 2011, was 150 percent higher than average. During the flooding period, river flows of the four major Chao Phraya River tributaries (Ping, Wang, Yom, and Nan rivers) increased in the range of 1.4 to 5 times the average discharge. This study examined the river sediment discharge of the four major rivers in the upper Chao Phraya River basin in Thailand. The four rivers are considered the main sources of sediment supply to the Chao Phraya Estuary. River surveys of the Ping, Wang, Yom, and Nan rivers were carried out in October 2011 (during the great flood) and October 2012 (one year after the flood). Survey data included river cross sections, flow velocities, suspended sediment concentrations, and bed load transport in each river. Analyses of these data indicated that total sediment transport rates for the four main rivers during the flooding of 2011 were 2.3-5.6 times higher than the average sediment discharge over 60 years. The Flood of 2011 significantly affected the sediment characteristics including the proportions of suspended and bed sediment loads in each river though in different ways. The rates of sediment transport per unit discharge for the Ping and Wang rivers dramatically increased during the 2011 Flood, but the flooding had minimal effects on the sediment characteristics in the Yom and Nan rivers. The amount of total sediment discharge in each river caused by the 2011 flooding varied between 0.3 and $1.6 \mathrm{Mt}$. Additionally, the bed load transport in these rivers varied between $\sim 0 \%$ and $26 \%$ of the suspended sediment discharge.
\end{abstract}

KEY WORDS: Bedload, sediment discharge, sediment transport rates, Upper Chao Phraya River basin, flooding 


\section{Introduction}

In 2011, Thailand experienced the most severe flooding in the past 50 years caused by excessive and continuous rainfall from consecutive, powerful monsoons and tropical storms. The floods started in June 2011 in the northern regions of Thailand with tropical storm Haima, which carried 128 percent of the average rainfall for June, followed rapidly by tropical storm Nock-Ten throughout parts of July and August. As a result, rainfall was more than 150 percent of the average for both months (July-176 $\mathrm{mm} / \mathrm{mo}$, August- $225 \mathrm{~mm} / \mathrm{mo}$ ). Storms continued to hit the country from the north and the east and rainfall remained 135 percent and 116 percent above average throughout September and October, respectively. The above average precipitation from months of storms resulted in flooding of the central regions of Thailand. The flood covered more than $60,000 \mathrm{~km}^{2}$ of land in 66 of the country's 77 provinces. The floods impacted heavily on the private sector, particularly manufacturing, tourism, housing, agriculture, and the financial sector. The largest impact came from losses in physical assets, products, raw materials, machinery, accommodations, transportation, food, and household goods. It had an effect on more than 13 million people from July through December 2011 (World Bank, 2012).

Flooding occurred in the downstream parts of the Nan and Yom rivers, which are present in the upper watershed of the Chao Phraya River (Fig. 1). All floodwaters in the upper watershed including the Ping, Wang, Yom, and Nan rivers drain into the lower Chao Phraya River at Nakhon Sawan. The total discharge during the 2011 Flood at Nakhon Sawan was 32.6 billion $\mathrm{m}^{3}$, which was $232 \%$ of the average value for 1956-1999 (Komori et al., 2012).

The Chao Phraya River is the major drainage basin in Thailand, with a total surface area of approximately $180,000 \mathrm{~km}^{2}, 35 \%$ of the total surface area of the country. The river arises in the Central Cordillera near the Thai-Myanmar-Laos borders, and flows southward into the Gulf of Thailand (Alford, 1992). The Chao Phraya River basin is considered to be the main source of sediment supply to the Gulf of Thailand. Therefore, changes of flow characteristics in the upper watershed of the Chao Phraya River due to the flood in 2011 might be expected to directly affect the sediment process in those rivers and also affect the sediment supply to the Chao Phraya Estuary. The purpose of this study was to examine the effects of Thailand's great flood of 2011 on river sediment discharge in the four major rivers (Ping, Wang, Yom, and Nan rivers) that are the main sources of sediment supply to the Chao Phraya Estuary.

\section{Study Area}

The Ping River basin, one of the largest sub-basins in the upper Chao Phraya basin, is located between latitudes $15^{\circ} 45^{\prime} \mathrm{N}$ to $19^{\circ} 45^{\prime} \mathrm{N}$ and longitudes $98^{\circ} 06^{\prime} \mathrm{E}$ to $100^{\circ} 12^{\prime} \mathrm{E}$. The river basin is mainly characterized by terraced mountains with a catchment area of $34,453 \mathrm{~km}^{2}$. It covers about $22 \%$ of the Chao Phraya River basin and contributes about $24 \%$ of the total average annual runoff. The climate of the basin is characterized by average annual rainfall of $1,097 \mathrm{~mm}$ (Sharma et al., 2007). The Ping River length is approximately $740 \mathrm{~km}$ (Wuttichaikitcharoen \& Babel, 2014) with the river slope varying from 1:40 to 1:2,300 (Hydro and Agro Informatics Institute [Haii], 2014).

The Wang River basin is the smallest river sub-basin of the upper Chao Phraya River basin. It is located between $17^{\circ} 05^{\prime} \mathrm{N}-19^{\circ} 30^{\prime} \mathrm{N}$ latitude and $98^{\circ} 54^{\prime} \mathrm{E}-99^{\circ} 58^{\prime} \mathrm{E}$ longitude, and the topography is characterized by terraced mountains. The watershed area of the Wang River is $10,800 \mathrm{~km}^{2}$ (Komori et al., 2012). The average annual precipitation is $1,100 \mathrm{~mm}$. The length of the Wang River is $460 \mathrm{~km}$ (Wuttichaikitcharoen \& Babel, 2014), and the river gradient is between 1:60 and 1:1,990 (Haii, 2014).

The Yom River basin is located between $17^{\circ} 30^{\prime} \mathrm{N}-19^{\circ} 30^{\prime} \mathrm{N}$ latitude and $99^{\circ} 20^{\prime} \mathrm{E}-100^{\circ} 40^{\prime} \mathrm{E}$ longitude, having a catchment area of $12,580 \mathrm{~km}^{2}$. The topography of the basin varies from hilly areas in the northern part to lowland flat areas in the southern part. The climate of the basin is characterized by tropical monsoons, with a mean annual rainfall of $1,250 \mathrm{~mm}$. Rainfall distribution is generally uniform over the entire basin (Tingsanchali \& Karim, 2010). The Yom River has a length of about $735 \mathrm{~km}$ (Wuttichaikitcharoen \& Babel, 2014), and the river slope varies from 1:700 to 1:35,000 (Haii, 2014).

The Nan River basin is located between latitudes $15^{\circ} 42^{\prime} \mathrm{N}$ to $18^{\circ} 37^{\prime} \mathrm{N}$ and longitudes $99^{\circ} 51^{\prime} \mathrm{E}$ to $101^{\circ} 21^{\prime} \mathrm{E}$ with a watershed area of $34,682 \mathrm{~km}^{2}$. The average annual rainfall in the basin is $1,204 \mathrm{~mm}$ and the topography is characterized by mountains and floodplain areas (Amnatsan et al., 2009). The Nan river length is $770 \mathrm{~km}$ (Wuttichaikitcharoen \& Babel, 2014) with the river gradient varying from 1:480 to $1: 13,000$ (Kitisuntorn, 1994). 


\section{Methods}

Historical streamflow and sediment data collected by the Royal Irrigation Department (RID) were used for studying the average river flow conditions and sediment characteristics of the Ping, Wang, Yom, and Nan rivers. Unfortunately, sediment data in Thailand are insufficient for detailed studies, especially bed load which is generally not available in Thailand. Turowski et al. (2010) indicated that it has been frequently found that the bed load fraction is $10 \%$ to $20 \%$ in general, and sometimes $20 \%$ to $40 \%$ for mountainous rivers. For river sediment studies in Thailand, bed load discharge has been generally estimated as 30\% of suspended load (Tae-Sombat, 1988). However, sediment transport processes are complicated and may vary due to local conditions such as climatic and geomorphological conditions, land use, etc. (Wuttichaikitcharoen \& Babel, 2014). Kitisuntorn (1994) conducted 22 intervals of sediment sampling in the Nan River from June 1992 to December 1992 for assessing the sediment transport rate in the Nan River. He found that the bed load to suspended load ratios varied from $1 \%$ to $2 \%$ (September-December 1992). Additionally, Chanyotha and Chatchawan (1995) studied sediment transport characteristics on the Mae Kok River in Chiang Rai Province, and their results indicated that the bed load is approximately 38\% of suspended load. Therefore, considering bed loads as $30 \%$ of suspended loads may not be appropriate for all rivers of the Chao Phraya basin. River surveys during the flood of 2011, and one year after the flood, were necessary for assessing effects of the flood of 2011 on sediment discharge.

River surveys were carried out as part of this study to quantify river discharge, flow depth, flow velocity, suspended sediment, and bed load in the Ping, Wang, Yom and Nan rivers at Stations SP, SW, SY, and SN, respectively (Fig. 1). Field measurements were conducted on October 17-24, 2011 (during the Thailand Great Flood of 2011) and on October 15-20, 2012 (one year after the flooding).

Flow velocities were measured using an AEM1-D in-situ portable single-axis current meter which was designed for simple and accurate measurement. At each observing station, a measurement of the river depth was made along the transverse distance to provide a cross-sectional profile. To determine the mean flow velocity, six flow velocities were measured at various depths and averaged. The mean flow velocity was also obtained in the transverse direction to provide a plot of flow velocities along the cross-sectional profile.

The discharges in each river were determined by subdividing the river cross-section into a number of rectangular elements. The measured flow velocity at 0.4 times of sub-segment depth from the stream bottom in each rectangular element was used to approximate the average velocity for that element. Then, discharge was calculated by multiplying the average velocity for each element by the area of that element and summing across the stream (Hornberger et al., 1998).

Suspended sediment measurements were performed by an inverted and corked cylindrical bottle at the proportional depths of $0.2,0.4,0.6$, and 0.8 between the water surface and river bed. The samples were obtained by filtering suspended sediment through GIF filter paper that retained particles larger than 0.5 micrometers. The collected samples were analyzed and reported as suspended sediment concentration in parts per million $(\mathrm{mg} / \mathrm{l})$.

For bed load sampling, A Helley-Smith sampler was used to collect the bedload sediments. It was a medium-weight sampler installed with a flexible polyester sample bag. The sampler body was $0.46 \mathrm{~m}$ long and had a square nozzle, $0.078 \mathrm{~m}$ wide, at the sample entrance. The sample bag allowed the collection of gravel and sand larger than $0.25 \mathrm{~mm}$ in diameter. The flow velocities at which the sampler could be operated were limited to $2.5 \mathrm{~m} / \mathrm{s}$ or less. The sampling time was between 30 and $60 \mathrm{~s}$ for each measurement. Type of bed materials, bed load discharges, and particle size distribution were obtained from laboratory analysis using standard test methods for particle-size analysis of soils (ASTM D422).

\section{Results and Discussion}

A summary of field observation data in October 2011 and October 2012 is listed in Table 1, and Fig. 2 illustrates the observed sediment discharge (suspended load and bed load) during the flood of 2011 and during October 2012 at stations SP, SW, SY, and SN on the Ping, Wang, Yom and Nan rivers, respectively. The observed river flows and sediment characteristics for each river basin, including the average 
condition of the river and sediment discharge, are discussed in the following subsections.

\subsection{River Flow and Sediment Characteristics during the Great Flood of 2011}

Based on river surveys at Station SP (Fig.1) on the Ping River during the great flood of 2011, the river discharge was $1,412 \mathrm{~m}^{3} / \mathrm{s}$, with an average current velocity of $2.08 \mathrm{~m} / \mathrm{s}$. The spot measurements of suspended sediment concentration across the flow section varied from 40.5 to $1,127 \mathrm{mg} / \mathrm{l}$, which yielded a total suspended sediment discharge of about 35,299 tons/day. Based on the bed load samples, the Ping River bed material was very coarse sand with a median diameter, $\mathrm{d}_{50}$, of $1.13 \mathrm{~mm}$. The bed load samples along the cross section varied between 0.32 and $29.4 \mathrm{~g} / \mathrm{s}$, and the rate of bed load transport was 1,401 tons/day approximately ( $4 \%$ of suspended load). The total sediment transport rate in the Ping River was 36,700 tons/day.

The Wang River flow at Station SW was $263 \mathrm{~m}^{3} / \mathrm{s}$ with an average flow velocity of $1.40 \mathrm{~m} / \mathrm{s}$. The suspended sediment concentration varied from 160 to $770 \mathrm{mg} / \mathrm{l}$, and contributed a suspended sediment discharge of about 7,415 tons/day. The bed material mainly was very coarse sand with a $\mathrm{d}_{50}$ of $1.02 \mathrm{~mm}$. The movement of bed load varied from 1.36 to $9.58 \mathrm{~g} / \mathrm{s}$ across the flow section, and yielded a bed load discharge of 457 tons/day (6\% of suspended sediment discharge). Total sediment discharge was 7,873 tons/day.

The Yom River runoff at Station SY was $773 \mathrm{~m}^{3} / \mathrm{s}$ with an average current velocity of $1.83 \mathrm{~m} / \mathrm{s}$ during the observation. The suspended sediment concentration varied from 40 to $72 \mathrm{mg} / \mathrm{l}$, discharging a suspended load of approximately 3,710 tons/day. Bed load material mostly was very coarse sand with a $\mathrm{d}_{50}$ of $1.54 \mathrm{~mm}$. Bed load movement varied from 0.32 to $2.68 \mathrm{~g} / \mathrm{s}$, which yielded a bed load discharge of 172 tons/day (5\% of suspended load). The total sediment discharge was 3,882 tons/day.

The water discharge of the Nan River at Station SN was $847 \mathrm{~m}^{3} / \mathrm{s}$, and the average current velocity was $0.94 \mathrm{~m} / \mathrm{s}$. The suspended sediment concentration varied from 60 to $1,000 \mathrm{mg} / \mathrm{l}$, resulting in a suspended sediment discharge of 7,305 tons/day. The bed load sediment is medium sand with a $\mathrm{d}_{50}$ of $0.39 \mathrm{~mm}$. The bed load movement varied from 0.1 to $28 \mathrm{~g} / \mathrm{s}$ across the flow area, and yielded 1,040 tons/day of bed sediment transport in the Nan River (14\% of suspended sediment discharge). The total sediment transport rate was 8,346 tons/day.

Considering the total sediment transport rate per unit discharge $\left(\mathrm{S}_{\mathrm{T}} / \mathrm{Q}\right)$ in Table 1 , the $\mathrm{S}_{\mathrm{T}} / \mathrm{Q}$ in the four rivers during the 2011 flooding varied widely with the range of $5-29.9$ tons $/$ day $/\left(\mathrm{m}^{3} / \mathrm{s}\right)$. The $\mathrm{S}_{\mathrm{T}} / \mathrm{Q}$ were very high in the Ping and Wang rivers (26-29.9 tons $/$ day $/\left(\mathrm{m}^{3} / \mathrm{s}\right)$ ) compared to the Yom and Nan rivers, which yielded $\mathrm{S}_{\mathrm{T}} / \mathrm{Q}$ only 5-9.9 tons/day/( $\left.\mathrm{m}^{3} / \mathrm{s}\right)$.

\subsection{River Flow and Sediment Characteristics in 2012}

A second set of the river surveys were carried out during October 15-20, 2012, associated with a return to normal flow conditions following the 2011 flooding for assessing the effects of the flooding of 2011 on sediment discharge in each river. During this time period, the Royal Irrigation Department (RID, Thailand) controlled water levels in each river as part of the national flood preparation plan by lowering water level in Bhumibol Dam and Sirikit Dam at the end of the dry season to increase reservoir storage during the wet season (Royal Irrigation Department [RID], 2013).

The observed streamflow discharge of the Ping River at Station SP was $224 \mathrm{~m}^{3} / \mathrm{s}$ with an average velocity of $0.90 \mathrm{~m} / \mathrm{s}$. The suspended sediment concentration varied from 33 to $78 \mathrm{mg} / \mathrm{l}$, yielding a suspended sediment discharge of 1,024 tons/day. The bed load movement varied from 8 to $200 \mathrm{~g} / \mathrm{s}$ which yielded a bed load discharge of 265 tons/day ( $26 \%$ of the suspended load movement). The total sediment discharge was 1,289 tons/day.

The river discharge at Station SW on the Wang River was $36 \mathrm{~m}^{3} / \mathrm{s}$ with average velocity of $0.61 \mathrm{~m} / \mathrm{s}$. The suspended sediment concentration varied from 39 to $67 \mathrm{mg} / \mathrm{l}$, and total suspended sediment discharge was approximately 163 tons/day. Bed load at Station SW was below the limits of detection. Therefore, the sediment discharge was considered to be 100 percent suspended sediment.

For the Yom River, the flow discharge at Station SY was $330 \mathrm{~m}^{3} / \mathrm{s}$ with average velocity of $1.07 \mathrm{~m} / \mathrm{s}$. The suspended sediment concentration varied from 79 to $113 \mathrm{mg} / \mathrm{l}$, and yielding a suspended sediment discharge of 1,903 tons/day. Similar to the Wang River, the bed load at station SW was not detectable.

At Station SN in the Nan River, the river flow was $121 \mathrm{~m}^{3} / \mathrm{s}$ with an average velocity of $0.64 \mathrm{~m} / \mathrm{s}$. The 
suspended sediment concentration varied from 81 to $133 \mathrm{mg} / \mathrm{l}$, and yielded a suspended sediment discharge of 1,082 tons/day. For bed load, it was found that the bed load movement varied from 58 to $68 \mathrm{~g} / \mathrm{s}$, yielding a bed load discharge of 120 tons/day (11\% of the suspended load movement). The total sediment discharge was 1,202 tons/day.

Figure 3 presents the relationship between observed water discharge and percentage of bed-to-suspended sediment $\left(\mathrm{S}_{\mathrm{b}} / \mathrm{S}_{\mathrm{s}}\right)$ for each river in this study including the observed sediment data on the Nan River from the study of Kitisuntorn (1994) and the sediment study results of Chanyotha and Chatchawan (1995).

Unlike in 2011, the $S_{\mathrm{T}} / \mathrm{Q}$ in the four rivers varied in narrow range of $4.6-10$ tons $/ \mathrm{day} /\left(\mathrm{m}^{3} / \mathrm{s}\right)$ as listed in Table 1. Even though, the Ping and Wang rivers contributed the highest $\mathrm{S}_{\mathrm{T}} / \mathrm{Q}$ during the flooding in 2011, they yielded significantly low $S_{T} / Q$ during normal flow conditions. For the Yom and Nan rivers, in contrast, the $\mathrm{S}_{\mathrm{T}} / \mathrm{Q}$ in 2012 was somewhat similar to that in 2011.

\subsection{Historical River Flow and Sediment Characteristics}

The daily river discharge data during 1952-2012 and daily suspended discharge from 1989 to 2009 were obtained from the Royal Irrigation Department for 4 stations: P2A, W4A, Y17, and N7A, which are located near the observation stations on the Ping, Wang, Yom, and Nan rivers, respectively. The locations of the RID's stations used in this study are indicated in Fig. 1. Time series of runoff and suspended sediment load at RID Stations: P2A, W4A, Y17, and N7A between 1952 and 2012 are shown in Figs. 4 and 5, respectively.

From statistical analysis, historical runoff at RID Stations P2A, W4A, Y17, and N7A are summarized in Table 2, it was found that the average discharge of the Ping River at RID Station P2A from 1952 to 2010 was approximately $206 \mathrm{~m}^{3} / \mathrm{s}$ and $262 \mathrm{~m}^{3} / \mathrm{s}$ for the dry (Nov-Feb) and wet (May-Oct) seasons, respectively. The average suspended sediment load at RID Station P2A during 1989-2000 was 0.758 Mt/year. For the Wang River, the average river flows at RID Station W4A between 1952 and 2010 in the dry season was $13 \mathrm{~m}^{3} / \mathrm{s}$, and it was $62 \mathrm{~m}^{3} / \mathrm{s}$ in the wet season. The average suspended sediment rate during 1989-2008 was $0.543 \mathrm{Mt} /$ year. The average discharge in the Yom River at RID Station Y17 between 1967 and 2010 was $44 \mathrm{~m}^{3} / \mathrm{s}$ and $177 \mathrm{~m}^{3} / \mathrm{s}$ in the dry and wet seasons, respectively. However, the suspended sediment data at RID Station Y17, which was available only in 2002, was $1.232 \mathrm{Mt} /$ year. In the Nan River, the average discharge during 1998-2010 at RID Station N7A was $221 \mathrm{~m}^{3} / \mathrm{s}$ in the dry season, and it was 406 $\mathrm{m}^{3} / \mathrm{s}$ in the wet season. The average suspended sediment movement between 2001 and 2004 was 3.258 $\mathrm{Mt} / \mathrm{year}$.

Based on the collected monthly suspended sediment and river runoff data at RID Stations P2A, W4A, Y17, and N7A, the plot of suspended sediment discharges and corresponding river discharge (including the observed data from this study in 2011 and 2012) for each station is shown in Fig. 6. The log-log trends were determined from best-fit regression analysis, and the relationship between suspended sediment transport rate and stream flow of each river developed from the regression analysis are:

$$
\begin{array}{ll}
\text { Ping River (P2A): } & S_{s}=0.81 Q^{1.343} \\
\text { Wang River (W4A): } & S_{s}=2.271 Q^{1.376} \\
\text { Yom River (Y17): } & S_{s}=10.506 Q^{0.876} \\
\text { Nan River (N7A): } & S_{s}=1.29 Q^{1.342}
\end{array}
$$

where $S_{s}$ is the suspended sediment discharge (tons/day) and $Q$ is water discharge $\left(\mathrm{m}^{3} / \mathrm{s}\right)$. The equations show high correlation between suspended load and flow discharge with correlation coefficients between 0.81 and 0.99 .

\subsection{Estimated Long-term Sediment Discharge}


For bed load discharge, the bed load estimations are based on the ratio of bed load to suspended load of each river from the measurements in October 2011 and 2012. However, the bedload to suspended load ratios in 2011 are different from the 2012 ratios. The river discharge in 2012 was much less than the runoff in 2011, and in some rivers (Wang River and Yom River), bed load transport was undetectable in October 2012 even during the wet season. The abnormally low stream flow rate in the four rivers in 2012 was caused by the flood preparation policy of the Thailand government in 2012.

Due to the strong correlation between suspended sediment discharge and river runoff, long-term suspended sediment load can be estimated from historical river water discharges, which have been measured daily by the RID since 1952 (P2A and W4A), 1967 (Y17), and 1998 (N7A). Figure 7 illustrates the monthly variability of estimated suspended sediment load over a 60-year period (1952-2012) at the RID Stations P2A, W4A, Y17, and N7A. Their average monthly suspended sediment loads are shown in Fig. 8.

For bed material transport in each river, when the suspended load is known, then the bed load can be estimated from bed-to-suspended ratios (Table 1). However, the 2011 sediment ratios for all four rivers were different from the 2012 ratios, due to the difference in flow rates. The flow rate in 2012 of each river was approximately the same as to the long-term average river discharge, so the 2012 sediment ratio was used for estimating long-term bedload in each river in this study.

Total sediment discharge was estimated by combining suspended load and bedload. The time series of total sediment discharge and monthly average total sediment discharge for the rivers is shown in Figs. 9 and 10, respectively. It was found that the sediment discharge in the four main rivers were high between August and October.

\subsection{The Effects of the Great Flood of 2011 on Sediment Discharge}

In this study, the effects of the 2011 Flood on sediment discharge on the main rivers in the Upper Chao Praya River basin were evaluated by either comparing the observed flow and sediment data during the flooding of 2011 to the average flow conditions or to the observed data at the same stations and same month in 2012 and the estimated sediment data from daily river discharge data between 1952-2012. Based on the RID's daily river discharge at P2A, W4A, Y17, and N7A, the daily suspended sediment load for each river can be estimated using Equations 1 to 4 . Knowing the suspended load, the proportion of bed load to suspended load from sediment measurement in 2012, which represents normal flow conditions for each river, was used for estimating the daily bed load over the long-term period (1952-2010 and 2012). Meanwhile, the daily bed load in 2011 was calculated based on the bed load to suspended load relationship observed in 2011. The average calculated sediment discharge at P2A, W4A, Y17, and N7A during the wet season and dry season are listed in Table 3. The effects of flooding on sediment characteristics of the Ping, Wang, Yom, and Nan rivers are discussed in the following subsections.

\subsubsection{Ping River}

The observed discharge in the Ping River during October of 2011 was 6.3 times higher than the discharge in October 2012, and the magnitude of the discharge was higher than other rivers during the flooding (Table 1). The observed river current in October 2011 was 2.3 times the current velocity observed in 2012. The current induced a bed load transport rate 5.3 times the 2012 rate. The suspended transport load was 35 times greater than the rate in 2012 (Table 1). As a result of the large mountain catchment area of the Ping River basin and 5 months of continuous rainfall in 2011, the basin produced significant amounts of sediment that were eventually transported into the Ping River during the flooding in 2011. Consequently, the ratio of suspended load to bed load during the 2011 flood was 25:1. The same ratio in 2012 was significantly lower $(4: 1)$. This difference is believed reflect the effect of Bhumibol Dam (13,463 million $\mathrm{m}^{3}$ ), which is one of the larger dams in Thailand. During the observation period in 2011, the dam had reached its maximum storage capacity. For dam safety, all inflow into the dam at that time had to be diverted downstream, bypassing storage within the reservoir. This rerouting of stream flow might be the major cause of the high suspended sediment concentration in 2011. Conversely, because of the flood protection policy in 2012, the water level in the dam was lowered in order to increase water storage during the wet season, but the inflow in 2012 was not as high 
as in 2011. From field observation in 2012, it was found that water released from Bhumibol Dam had a relatively low suspended sediment concentration compared to the 2011 period. This evidence supports the hypothesis of Walling and Fang (2003) that reservoir construction represents the primary cause of suspended sediment reduction in rivers.

The bed load transport rate during the Flood of 2011, even though the upstream bed load may have been sequestered behind Bhumibol Dam, was still high compared to the bed sediment transport rate in 2012. The strong river currents during the wet season in both 2011 and 2012 in the Ping River resulted in transport of bed material below the dam. However, because of the extremely high suspended sediment transport in 2011, caused by the Flood of 2011 and the significantly low suspended sediment transport in 2012, produced by water storage by Bhumibol Dam, the bed-to-suspended sediment transport ratios in the Ping River were considerably different between regulated (2012) and unregulated (2011) flow conditions. The results of this study suggest that the bedload transport rates were $4 \%$ and $26 \%$ for the unregulated flow and regulated flow conditions, respectively.

According to the total sediment transport rate per unit discharge $\left(\mathrm{S}_{\mathrm{T}} / \mathrm{Q}\right)$ in Table 1 , it was found that the $\mathrm{S}_{\mathrm{T}} / \mathrm{Q}$ in the Ping River in 2012 was only 5.7 tons $/ \mathrm{day} /\left(\mathrm{m}^{3} / \mathrm{s}\right)$, but it increased to 26 tons $/ \mathrm{day} /\left(\mathrm{m}^{3} / \mathrm{s}\right)$ during the Flood of 2011. Obviously, the 2011 Flood caused a significant effect on the sediment transport rate in the Ping River.

Even though, the observed river discharge in the Ping River in October 2011 was dramatically high compared to the river discharge in 2012, the average river discharge during the wet season (May-Oct) in the Ping River through flooding of 2011 was only 2 times higher than the average runoff over the past six decades (1952-2010 and 2012) as shown in Table 2. Based on calculated sediment discharge during the wet season in Table 3, it was found that the Ping River basin yields an average total sediment load during the wet season of $0.384 \mathrm{Mt} / \mathrm{yr}\left(13 \mathrm{tons} / \mathrm{km}^{2} / \mathrm{yr}\right)$, and the 2011 Flood caused total sediment discharge approximately $0.5 \mathrm{Mt}$ higher than the average total sediment discharge over long periods. As a result of the 2011 Flood, the Ping River basin yielded an extra 17.8 tons $/ \mathrm{km}^{2}$ of total sediment to the river system.

\subsubsection{Wang River}

The Wang River basin is relatively similar in catchment area characteristics to the Ping River basin, but it is about one-third of the Ping River catchment area. The flow characteristics during the Flood of 2011 were also similar to the Ping River. The discharge at Station SW in October 2011 was 7.3 times higher than in October 2012, and the current velocity was 2.3 times higher. The suspended sediment transport rate in 2011 was approximately 46 times higher than the 2012 observed suspended transport rate. The strong current in October 2011 produced a bed load transport rate which was 6\% of the suspended sediment transport in the river, but almost $100 \%$ of sediment transport in this river on October 2012 was suspended load. Although, there is a large dam, Kew Lom Dam, located at $230 \mathrm{~km}$ above the confluence of the Wang River and the Ping River (Fig.1), the size of the reservoir is relatively small compared to the reservoir at Bhumibol Dam. Hence, river flow measured at Station SW is considered to be unregulated. The Kew Lom Reservoir has a storage capacity of only 122 million $\mathrm{m}^{3}$ (about 10 times less than Bhumibol Dam), and the dam always reaches its storage capacity during the wet season. The Wang River basin is the smallest drainage area of the four river basins, but the 2011 Flood also carried a large amount of suspended material into the Wang River. By comparing the bed-to-suspended sediment transport ratios between the Ping River and the Wang River under unregulated flow conditions during the Flood of 2011, it can be observed that both rivers are similar in sediment transport characteristics.

For the Wang River, the 2011 Flood had immense effects on river flow and sediment characteristics. From Table 1, the $S_{\mathrm{T}} / \mathrm{Q}$ in the Wang River in 2012 was 4.6 tons $/$ day $/\left(\mathrm{m}^{3} / \mathrm{s}\right)$, which was slightly less than the $S_{\mathrm{T}} / \mathrm{Q}$ in the Ping River for the same period of measurement. Similar to the Ping River, the $S_{\mathrm{T}} / \mathrm{Q}$ in the Wang River spectacularly rose to 29.9 tons $/$ day $/\left(\mathrm{m}^{3} / \mathrm{s}\right)$ caused by the 2011 Flood. The average discharge during the flooding (May-Oct) period in 2011 was 3.9 times greater than the average discharge over the 60-year period (1952-2012) as shown in Table 2. The average annual total sediment load during the wet season is $0.175 \mathrm{Mt} / \mathrm{yr}\left(16 \mathrm{tons} / \mathrm{km}^{2} / \mathrm{yr}\right)$, but the additional sediment yield from the Wang River caused by the 2011 Flood was $0.8 \mathrm{Mt}$ or $74 \mathrm{tons} / \mathrm{km}^{2}$, which is significantly higher than the Ping River sediment yield during the wet season of 2011. The Ping and Wang rivers have similar geologic and topographic characteristics, land use within their drainage basins, and sediment transport 
characteristics. The difference in sediment yields might reflect the difference in hydrologic characteristics, such as rainfall intensity, and rainfall duration during the 2011 Flood between these two river basins. However, the study of hydrologic characteristics among the rivers in the Upper Chao Phraya River basin is beyond the scope of this paper. Further studies on this issue will be addressed in later reports.

\subsubsection{Yom River}

The Yom River basin is slightly larger than the Wang River basin. However, the catchment area of the Yom River basin is characterized by lowlands with gentle river slopes compared to the Ping and Wang river basins. There are no large dams in the Yom River system, so the flow behavior in this river basin is unregulated. During the Flood of 2011 the river had 2.3 times the discharge as in October 2012. Considering the observed current speeds for October 2011 and October 2012 in Table 1, it was found that the observed current speed in 2011 was $1.83 \mathrm{~m} / \mathrm{s}$, which was 1.7 times higher than the observed current velocity in 2012. The high current velocity in 2011 resulted in a bed sediment transport rate of 172 tons/day. Although the current speed in the Yom River in 2012 was more than $1 \mathrm{~m} / \mathrm{s}$, the bedload movement at Station SY was undetectable in October 2012 because the river sediment transport capacity depends on many variables, such as water discharge, average flow velocity, particle size and its gradation, water temperature, bed shear stress, energy slope, channel shape, etc. (Yang, 2005). The rate of observed suspended sediment movement during the Flood of 2011 was 2 times greater than the observed suspended sediment discharge in 2012. Nonetheless, the suspended sediment transport rate in the Yom River during the Flood of 2011 was significantly low compared to the Ping and Wang rivers. From the observed sediment data, the percentage bedload to suspended sediment transport rates in the Yom River during the 2011 Flood was 5\%, but the bed load sediment transport was underdetecable in 2012. From Table 1, the $\mathrm{S}_{\mathrm{T}} / \mathrm{Q}$ in the Yom River in 2011 (5.0 tons $/$ day $/\left(\mathrm{m}^{3} / \mathrm{s}\right)$ ) was slightly less than in 2012 (5.8 tons $/$ day $/\left(\mathrm{m}^{3} / \mathrm{s}\right)$ ). It seems that the Flood of 2011 slightly modified the sediment transport characteristics in the Yom River. Moreover, the results from sediment analysis also show that the Flood of 2011 had less effect on suspended and bedload transport rates for the Yom River compared to the Ping and Wang rivers. This might possibly have been caused by the low relief of the basin and the coarse sediment size in the Yom River.

The Yom River during the flood season of 2011 had an average discharge about 5 times higher than the long-term average discharge (Table 2). However, the Flood of 2011 yielded a total sediment load only 2.8 times higher than average total sediment discharge. The Yom River basin produced additional sediment yield of about $23.8 \mathrm{ton} / \mathrm{km}^{2}$ during the Flood of 2011. Table 3 shows that the annual total sediment transport during the wet season in the Yom River basin was $0.47 \mathrm{Mt}$, which was $0.3 \mathrm{Mt}$ higher than the average condition. In other words, the Yom River basin yields an extra sediment load of 24 tons $/ \mathrm{km}^{2}$ due to the influence of the 2011 Flood.

\subsubsection{Nan River}

The Nan River basin is similar in size to the Ping River, but it consists of both mountain and flood plain terrain. The Sirikit Dam $\left(9,510\right.$ million $\left.\mathrm{m}^{3}\right)$ is located approximately midway along the river's course. The river basin above the dam has steep slopes. Meanwhile, the lower part of the basin below the dam consists of mostly flat floodplain. During the Flood of 2011, the Nan River's discharge at station SN was 7.0 times higher than the discharge in October 2012. The observed velocities during October 2011 and October 2012 were 0.94 and $0.64 \mathrm{~m} / \mathrm{s}$, respectively. Although, the current velocities for both periods of observations were relatively low compared to the other rivers (Table 1), the current during the wet periods was strong enough to induce bedload transport in the river because the bed materials in the Nan River were finer than those in the other rivers. The suspended sediment transport rate in the Nan River during the Flood of 2011 was 6.8 times higher than the suspended load movement in 2012. Conversely, the bedload transport rate during Flood of 2011 in the Nan River was 8.7 times greater than the bed load discharge in 2012.

For the Nan River, the river flow hydraulics in October 2011 could be considered as unregulated flow conditions because the water level at Sirikit Dam had reached the reservoir capacity. Similar to Bhumibol Dam, all inflow from upstream of Sirikit Dam at that time was released downstream. 
However, the results of this study show that the bed-to-suspended sediment transport ratio on the Nan River in October 2011 and October 2012 were 14\% and 11\%, respectively. The sediment transport ratio for the Nan River basin seems to be slightly modified by the Flood of 2011. Therefore, Sirikit Dam appears to have had an insignificant effect on sediment transport characteristics in the Nan River because the location of the dam is relatively far from the observation station compared to the effects of Bhumibol Dam on the Ping River system. According to the study of Kitisuntorn (1994), the sediment transport rate was measured on the lower part of the Nan River from approximately $50 \mathrm{~km}$ downstream of Station SN to the confluence of the Ping and Nan rivers at Nakhon Sawan. However, his results showed that the bed-to-suspended sediment transport ratios for the lower part of the Nan River varied between $1 \%$ and 2\%. Kitisuntorn's (1994) study area was relatively flat compared to the others part of the Nan River. He also mentioned river bank instability in his study area. The difference in sediment transport ratios between Kitisuntorn (1994) and this study might be caused by the different locations of the study areas. However, land use changes between 1994 and 2011, and differences in hydrologic conditions may have influenced the characteristics of sediment transport in the Nan River. Further studies of the effects of these factors on sediment characteristics in the Nan River are needed.

Under normal flow conditions in 2012, the Nan River had the highest $\mathrm{S}_{\mathrm{T}} / \mathrm{Q}\left(10\right.$ tons $\left./ \mathrm{day} /\left(\mathrm{m}^{3} / \mathrm{s}\right)\right)$ compared to the other rivers (Table 1). However, similar to the Yom River, the Flood of 2011 had an insignificant effect on the total sediment transport per unit discharge in the Nan River. The changes in sediment transport rate per unit discharge in the Nan River and the Yom River-which can be considered as river basins with mild slope-, caused by the Flood of 2011 are opposite to the mountainous river basins (Ping and Wang rivers). This might reflect how the basin and river gradients affected the difference in sediment transport characteristics among these river basins under large flood conditions. The total amount of sediment transport in the Yom and Nan rivers in 2011 was much larger than in 2012 because the increased runoff eroded and transported more soil from overbank lands and river channel surfaces. However, sediment loads from land surface erosion mostly deposited on lowland flood plains, which are known as important sinks for storing fine sediment during flood events (Walling \& He, 1997), and did not reach the river channel. The effect of sedimentation on the flood plains resulted in the insignificant changes in $\mathrm{S}_{\mathrm{T}} / \mathrm{Q}$ in the Yom and Nan rivers during the Flood of 2011.

Because the highest value of $\mathrm{S}_{\mathrm{T}} / \mathrm{Q}$ occurs in the Nan River, the Nan River also yields the highest amount of annual total sediment load compared to the other rivers. Even though, the Flood of 2011 had an insignificant effect on the sediment transport characteristics in the Nan River, it still yielded the highest total sediment discharge in 2011. This might relate to the effects of hydrological conditions, especially rainfall duration, on the sediment yield of the river system.

\section{Conclusions}

This study has demonstrated the characteristics of river flow and sediment transport rate of the four main rivers (Ping, Wang, Yom, and Nan rivers) in the Chao Phraya River basin in Thailand during the Great Flood of 2011. River surveys were carried out for data collection along river cross sections, including flow velocities, and suspended and bed sediment loads, on October 17-21, 2011 and on October 15-20, 2012. The characteristics of sediment transport in each river were investigated and were used in estimating long-term river sediment loads. By comparing the flow and the sediment characteristics during the wet season in 2011, 2012, and the average conditions over 60 years, the effects of the Great Flood of 2011 on sediment discharge in each river can be assessed. The results of this study indicate that the Flood of 2011 induced a river discharge in these rivers 1.4-5 times higher than the long term average. Consequently, each river basin yielded total sediment transport of 0.3-1.6 Mt higher than long-term average conditions. The Nan River and Wang River basins contributed significantly higher amounts of sediment yield per unit area compared to the Ping River and the Yom River basins.

Based on the sediment transport rate per unit discharge $\left(\mathrm{S}_{\mathrm{T}} / \mathrm{Q}\right)$ in each river observed in 2012, it was found that the $\mathrm{S}_{\mathrm{T}} / \mathrm{Q}$ in the Ping, Wang, Yom, and Nan rivers varied in a narrow range of 4.6-10.0 tons $/$ day $/\left(\mathrm{m}^{3} / \mathrm{s}\right)$. However, because of the Flood of 2011, the $\mathrm{S}_{\mathrm{T}} / \mathrm{Q}$ in the Ping and Wang rivers, which are mountainous river basins, dramatically increased to 26.0 and 29.9 tons $/ \mathrm{day} /\left(\mathrm{m}^{3} / \mathrm{s}\right)$, respectively. Meanwhile, the $\mathrm{S}_{\mathrm{T}} / \mathrm{Q}$ in the low relief river basins (Yom and Nan rivers) were not modified by the flooding. This may reflect the influence of landform types and river gradients on sediment transport 
characteristics among these river basins under large flood conditions.

The Flood of 2011 also had an impact on sediment transport characteristics of each river. During the 2011 Flood, which can be considered as unregulated flow conditions, the ratio between bed load transport and suspended sediment transport were 4\%-6\% for very coarse sandy rivers (Ping, Wang, and Yom rivers) and approximately $14 \%$ for a medium coarse sandy river (Nan River). However, during a normal wet season in which river discharge normally is regulated, the bed-to-suspended transport ratio of these rivers varies between $\sim 0 \%-26 \%$, being affected by flow conditions, sediment material, river basin topography, size and location of reservoir construction, and hydrologic conditions, such as rainfall intensity and duration. Therefore, traditional estimates of bed load as $30 \%$ of suspended load might not be appropriate to apply to these rivers. The ratios of bedload to suspended load at the Ping, Wang, Yom, and Nan rivers found in this study (Table 1) are recommended as a guideline for more realistic sediment transport estimation instead of using the traditional value of $30 \%$.

\section{Acknowledgements}

This study was partially supported by the Water Resources Engineering Department, Chulalongkorn University and the Science and Technology Research Partnership for Sustainable Development, JST-JICA, Japan. The authors are grateful to the two reviewers and the Editor of IJSR for their suggestions and support for improving the manuscript.

\section{References}

Alford, D. (1992). Streamflow and sediment transport from mountain watersheds of the Chao Phraya Basin, northern Thailand: a reconnaissance study. Mountain Research and Development, 12(3), 257-268.

Amnatsan, S., Fowze, J. S. M., Bormudoi, A., Hazarika, M. Z., \& Samarakoon, L. (2009). Flood hazard mapping in Nan River, Thailand. In Proceedings of the $7^{\text {th }}$ Annual Mekong Flood Forum, Bangkok, Thailand, pp. 297-303.

Chanyotha, S., \& Chatchawan, T. (1995). Changes of stream channel configuration and geometry of the Mae Kok River near Amphor Muang, Chiang Rai. In Proceedings of the $2^{\text {nd }}$ National Convention on Civil Engineering, Chiang Mai, Thailand. pp. 246-260.

Hydro and Agro Informatics Institute (Haii). (2014). Thailand's watersheds. Retrieved from http://www.haii.or.th/wiki/index.php.

Hornberger, G. M., Raffensperger, J. P., Wiberg, P. L., \& Eshleman, K. N. (1998). Elements of Physical Hydrology. JHU Press.

Kitisuntorn, P. (1994). Sediment transport and navigation problem in lower Nan River (Unpublished doctoral dissertation). Chulalongkorn University, Thailand. (In Thai)

Komori, D., Nakamura, S., Kiguchi, M., Nishijima, A., Yamazaki, D., Suzuki, S., ... \& Oki, T. (2012). Characteristics of the 2011 Chao Phraya River flood in central Thailand. Hydrological Research Letters, 6(0), 41-46.

Royal Irrigation Department (RID). (2013). Prevention and Mitigation Plan for Water Disasters (Wet Season): 2013. Bangkok, Thailand. (In Thai)

Sharma, D., Gupta, A. D., \& Babel, M. S. (2007). Spatial disaggregation of bias-corrected GCM precipitation for improved hydrologic simulation: Ping River Basin, Thailand. Hydrology and Earth System Sciences Discussions, $11(4), 1373-1390$.

Tae-Sombat, V. (1988). Applied hydrology, Physic Center Press, Bangkok, Thailand. (In Thai)

Tingsanchali, T., \& Karim, F. (2010). Flood-hazard assessment and risk-based zoning of a tropical flood plain: case study of the Yom River, Thailand. Hydrological Sciences Journal, 55(2), 145-161.

Turowski, J. M., Rickenmann, D., \& Dadson, S. J. (2010). The partitioning of the total sediment load of a river into suspended load and bedload: a review of empirical data. Sedimentology, 57(4), 1126-1146.

Walling, D. E., \& Fang, D. (2003). Recent trends in the suspended sediment loads of the world's rivers. Global and Planetary Change, 39(1), 111-126.

Walling, D. E., \& He, Q. (1997). Use of fallout ${ }^{137} \mathrm{Cs}$ in investigations of overbank sediment deposition on river floodplains. Catena, 29(3), 263-282.

World Bank. (2012). Thai Flood 2011: Rapid assessment for resilient recovery and reconstruction planning. Washington, D.C. Retrieved from http://documents.worldbank.org/curated/en/2012/01/16360875/thai-flood-2011-rapid-assessment-resilient-recover y-reconstruction-planning-vol-2-2-final-report.

Wuttichaikitcharoen, P., \& Babel, M. S. (2014). Principal Component and Multiple Regression Analyses for the Estimation of Suspended Sediment Yield in Ungauged Basins of Northern Thailand. Water, 6(8), 2412-2435.

Yang, S. Q. (2005). Prediction of total bed material discharge. Journal of Hydraulic Research, 43(1), 12-22. 


\section{List of Tables}

Table 1 Summary of field observation data.

Table 2 River discharge at RID Stations in the Upper Chao Phraya River Basin.

Table 3 Summary of calculated sediment discharge at stations P2A, W4A, Y17, and N7A from 1952-2012.

\section{Figure Captions}

Fig. 1 Upper Chao Phraya River watershed study area and measurement stations.

Fig. 2 Observed sediment load during October 2011 and 2012 (Units: metric tons per day).

Fig. 3 Relationship between river water discharge and percentage of bed load to suspended load of rivers in Thailand during 1992-2012.

Fig. 4 Time series of river discharge at RID stations P2A, W4A, Y17, and N7A between 1952 and 2012.

Fig. 5 Time series of suspended load at RID stations P2A, W4A, Y17, and N7A between 1989 and 2009.

Fig. 6 Sediment rating curves for stations P2A, W4A, Y17, and N7A.

Fig. 7 Estimated monthly suspended load at stations P2A, W4A, Y17, and N7A from 1952-2012.

Fig. 8 Average monthly suspended load at stations P2A, W4A, Y17, and N7A.

Fig. 9 Estimated monthly total sediment load at stations P2A, W4A, Y17, and N7A from 1952-2012.

Fig. 10 Average monthly total sediment load at stations P2A, W4A, Y17, and N7A. 


\begin{tabular}{|c|c|c|c|c|c|c|c|c|c|c|c|}
\hline Station & Date & $\begin{array}{l}\text { Flow } \\
\text { area } \\
\left(\mathrm{m}^{2}\right)\end{array}$ & $\begin{array}{c}\begin{array}{c}\text { Flow } \\
\text { velocity } \\
(\mathrm{m} / \mathrm{s})\end{array} \\
\end{array}$ & $\begin{array}{c}\text { Observed } \\
\text { discharge, Q } \\
\left(\mathrm{m}^{3} / \mathrm{s}\right)\end{array}$ & $\begin{array}{c}\text { Suspended } \\
\text { load, } \mathrm{S}_{\text {s }} \\
\text { (tons/day) }\end{array}$ & $\begin{array}{c}\text { Bed } \\
\text { load, } S_{\mathrm{b}} \\
\text { (tons } / \text { day) }\end{array}$ & $\begin{array}{c}\text { Total sediment } \\
\text { transport, } \mathrm{S}_{\mathrm{r}} \\
\text { (tons/day) }\end{array}$ & $\begin{array}{l}\mathrm{S}_{6} \\
(\%)\end{array}$ & $\begin{array}{l}S_{b} \\
(\%)\end{array}$ & $\begin{array}{l}\mathrm{S}_{\mathrm{f}} / \mathrm{S}_{\mathrm{s}} \\
(\%)\end{array}$ & $\begin{array}{c}\mathrm{S}_{\mathrm{T}} / \mathrm{Q} \\
\text { (tons } / \text { day) } /\left(\mathrm{m}^{3} / \mathrm{s} \text { ) }\right.\end{array}$ \\
\hline \multirow{2}{*}{ SP } & $20 / 10 / 11$ & 680.4 & 2.08 & 1,412 & 35,299 & 1,401 & 36,700 & 96 & 4 & 4 & 26.0 \\
\hline & $19 / 10 / 12$ & 249.4 & 0.90 & 224 & 1,024 & 265 & 1,289 & 79 & 21 & 26 & 5.7 \\
\hline \multirow{2}{*}{ SW } & $18 / 10 / 11$ & 188.2 & 1.40 & 263 & 7,415 & 457 & 7,873 & 94 & 6 & 6 & 29.9 \\
\hline & $19 / 10 / 12$ & 58.0 & 0.61 & 36 & 163 & n.d. & 163 & 100 & $\sim 0$ & $\sim 0$ & 4.6 \\
\hline \multirow{2}{*}{ SY } & $22 / 10 / 11$ & 421.9 & 1.83 & 773 & 3,710 & 172 & 3,882 & 96 & 4 & 5 & 5.0 \\
\hline & $17 / 10 / 12$ & 308.8 & 1.07 & 330 & 1,903 & n.d. & 1,903 & 100 & $\sim 0$ & $\sim 0$ & 5.8 \\
\hline \multirow{2}{*}{$\mathrm{SN}$} & $21 / 10 / 11$ & 899.4 & 0.94 & 847 & 7,305 & 1,040 & 8,346 & 88 & 12 & 14 & 9.9 \\
\hline & $18 / 10 / 12$ & 189.6 & 0.64 & 121 & 1,082 & 120 & 1,202 & 90 & 10 & 11 & 10.0 \\
\hline
\end{tabular}

Note. $\mathrm{S}_{\mathrm{s}}=$ Suspended load; $\mathrm{S}_{\mathrm{b}}=$ Bed load; $\mathrm{S}_{\mathrm{T}}=$ Total sediment load; $\mathrm{n} . \mathrm{d} .=$ not detected 


\begin{tabular}{|c|c|c|c|c|c|c|c|c|}
\hline \multirow{3}{*}{ Station } & \multirow{2}{*}{ Period } & \multicolumn{7}{|c|}{ Discharge $\left(\mathrm{m}^{3} / \mathrm{s}\right)$} \\
\cline { 3 - 8 } & & \multicolumn{2}{|c|}{ Dry season (Nov-Feb) } & \multicolumn{2}{|c|}{ Wet season (May-Oct) } & \multirow{2}{*}{ Annual } \\
\cline { 3 - 8 } & & $\mathrm{Q}_{\min }$ & $\mathrm{Q}_{\max }$ & $\mathrm{Q}_{\text {avg }}$ & $\mathrm{Q}_{\min }$ & $\mathrm{Q}_{\max }$ & $\mathrm{Q}_{\text {avg }}$ & \\
\hline \hline P2A & $1952-2010$ & $<1$ & 326 & 206 & 5 & 4,760 & 262 & 234 \\
& 2011 & 103 & 890 & 479 & 66 & 3,010 & 553 & 516 \\
& 2012 & 45 & 637 & 302 & 38 & 882 & 223 & 263 \\
\hline W4A & $1952-2010$ & $<1$ & 418 & 13 & $<1$ & 1,074 & 62 & 37 \\
& 2011 & 4 & 118 & 22 & 22 & 846 & 243 & 133 \\
& 2012 & 1.2 & 60 & 11 & $<1$ & 480 & 76 & 43 \\
\hline Y17 & $1967-2010$ & $<1$ & 555 & 44 & $<1$ & 1,784 & 177 & 111 \\
& 2011 & 155 & 736 & 385 & 184 & 1,541 & 887 & 331 \\
& 2012 & 122 & 152 & 218 & 127 & 298 & 168 & 92 \\
\hline N7A & $1998-2010$ & $<1$ & 920 & 221 & $<1$ & 1,786 & 406 & 313 \\
& 2011 & $<1$ & 590 & 100 & 34 & 1,502 & 562 & 636 \\
& 2012 & $<1$ & 324 & 16 & $<1$ & 947 & 376 & 317 \\
\hline
\end{tabular}




\begin{tabular}{|c|c|c|c|c|c|c|c|c|}
\hline \multirow[t]{2}{*}{ Station } & \multirow[t]{2}{*}{ Period } & \multicolumn{3}{|c|}{$\begin{array}{c}\text { Dry Season (Nov-Feb) } \\
\left(10^{6} \text { tons/year }\right)\end{array}$} & \multicolumn{3}{|c|}{$\begin{array}{c}\text { Wet Season (May-Oct) } \\
\left(10^{6} \text { tons/year }\right)\end{array}$} & \multirow{2}{*}{$\begin{array}{c}\text { Annual } \\
\mathrm{S}_{\mathrm{T}} \\
\left(10^{6} \text { tons }\right)\end{array}$} \\
\hline & & $\mathrm{S}_{\mathrm{S}}$ & $\mathrm{S}_{\mathrm{b}}$ & $\mathrm{S}_{\mathrm{T}}$ & $\mathrm{S}_{\mathrm{S}}$ & $\mathrm{S}_{\mathrm{b}}$ & $\mathrm{S}_{\mathrm{T}}$ & \\
\hline \multirow{3}{*}{$\mathrm{P} 2 \mathrm{~A}$} & $1952-2010$ & 0.206 & 0.053 & 0.259 & 0.305 & 0.079 & 0.384 & 0.643 \\
\hline & 2011 & 0.678 & 0.152 & 0.830 & 0.853 & 0.034 & 0.888 & 1.717 \\
\hline & 2012 & 0.243 & 0.063 & 0.307 & 0.237 & 0.062 & 0.299 & 0.606 \\
\hline \multirow{3}{*}{ W $4 \mathrm{~A}$} & $1952-2010$ & 0.021 & 0.000 & 0.021 & 0.175 & 0.000 & 0.175 & 0.196 \\
\hline & 2011 & 0.032 & 0.002 & 0.034 & 0.918 & 0.055 & 0.973 & 1.007 \\
\hline & 2012 & 0.013 & 0.000 & 0.013 & 0.214 & 0.000 & 0.214 & 0.227 \\
\hline \multirow{3}{*}{ Y17 } & $1967-2010$ & 0.046 & 0.000 & 0.046 & 0.169 & 0.000 & 0.169 & 0.215 \\
\hline & 2011 & 0.093 & 0.003 & 0.095 & 0.448 & 0.022 & 0.470 & 0.565 \\
\hline & 2012 & 0.018 & 0.000 & 0.018 & 0.169 & 0.000 & 0.169 & 0.187 \\
\hline \multirow{3}{*}{ N7A } & $1998-2010$ & 0.356 & 0.043 & 0.399 & 0.879 & 0.105 & 0.984 & 1.383 \\
\hline & 2011 & 0.707 & 0.090 & 0.797 & 2.303 & 0.322 & 2.625 & 3.422 \\
\hline & 2012 & 0.114 & 0.014 & 0.127 & 0.536 & 0.064 & 0.601 & 0.728 \\
\hline
\end{tabular}

Note. $\mathrm{S}_{\mathrm{s}}=$ Suspended load; $\mathrm{S}_{\mathrm{b}}=$ Bed load; $\mathrm{S}_{\mathrm{T}}=$ Total sediment load 


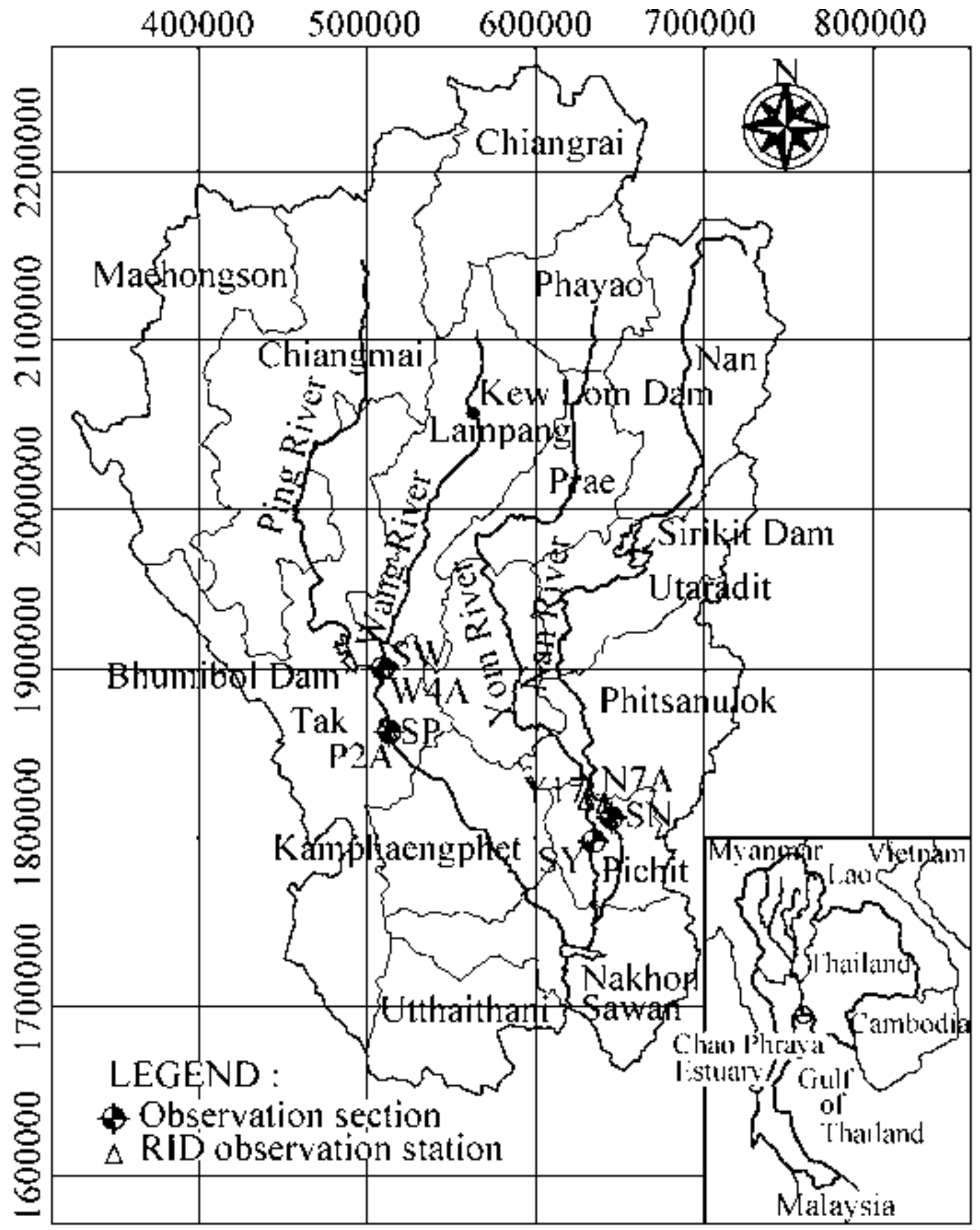

(JlM $/ 20 \mathrm{NJ}: 47 \mathrm{~N}$ 


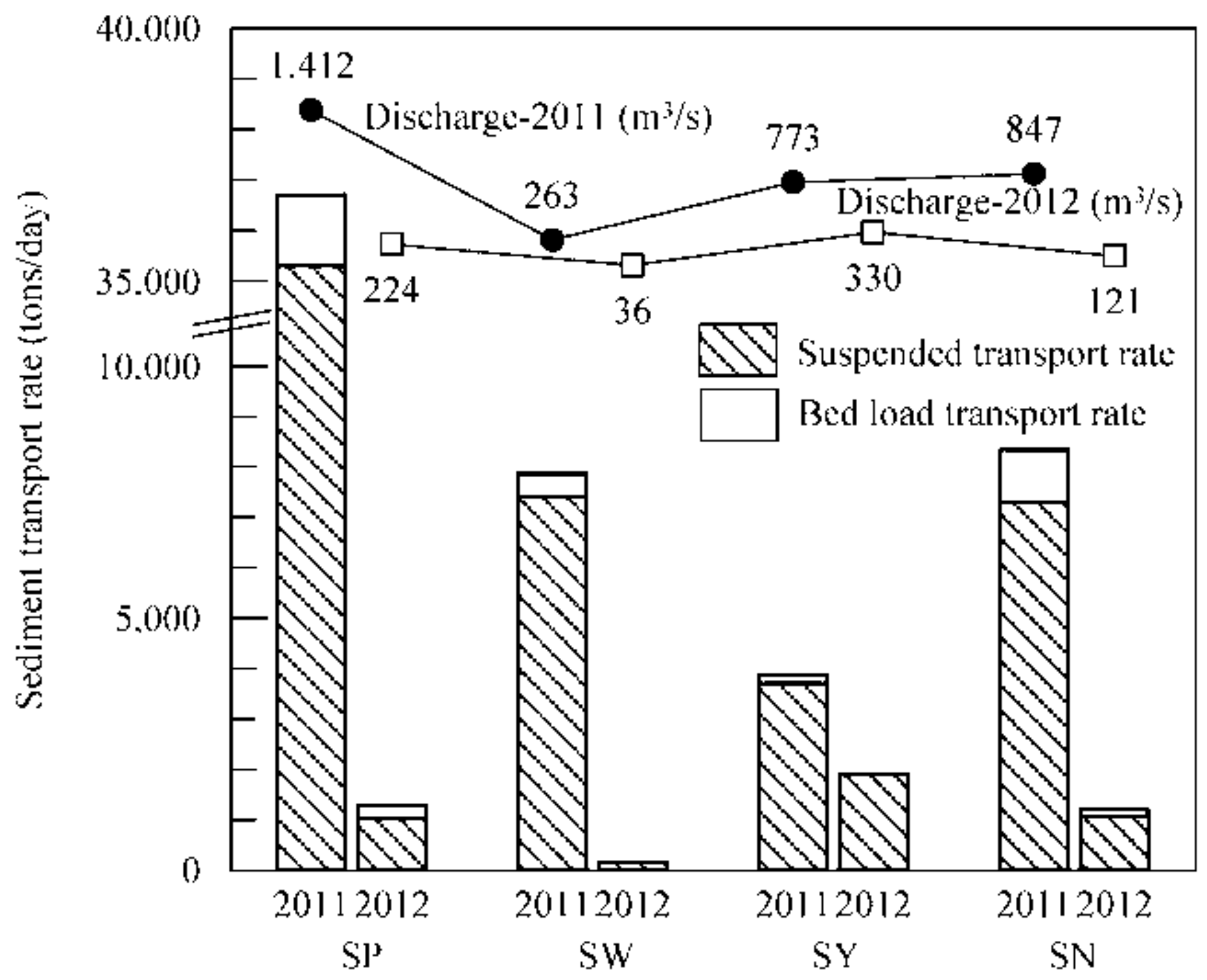




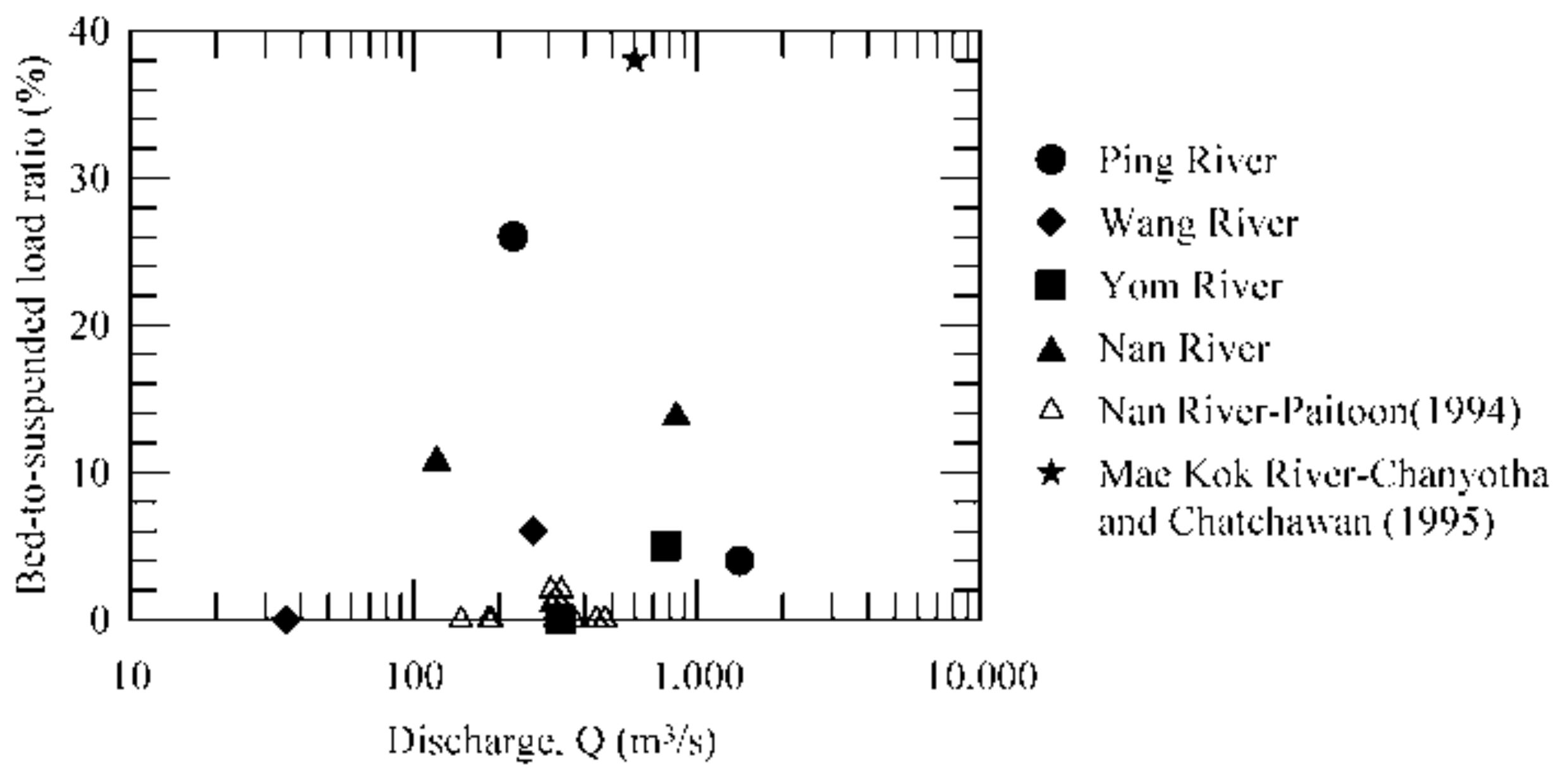



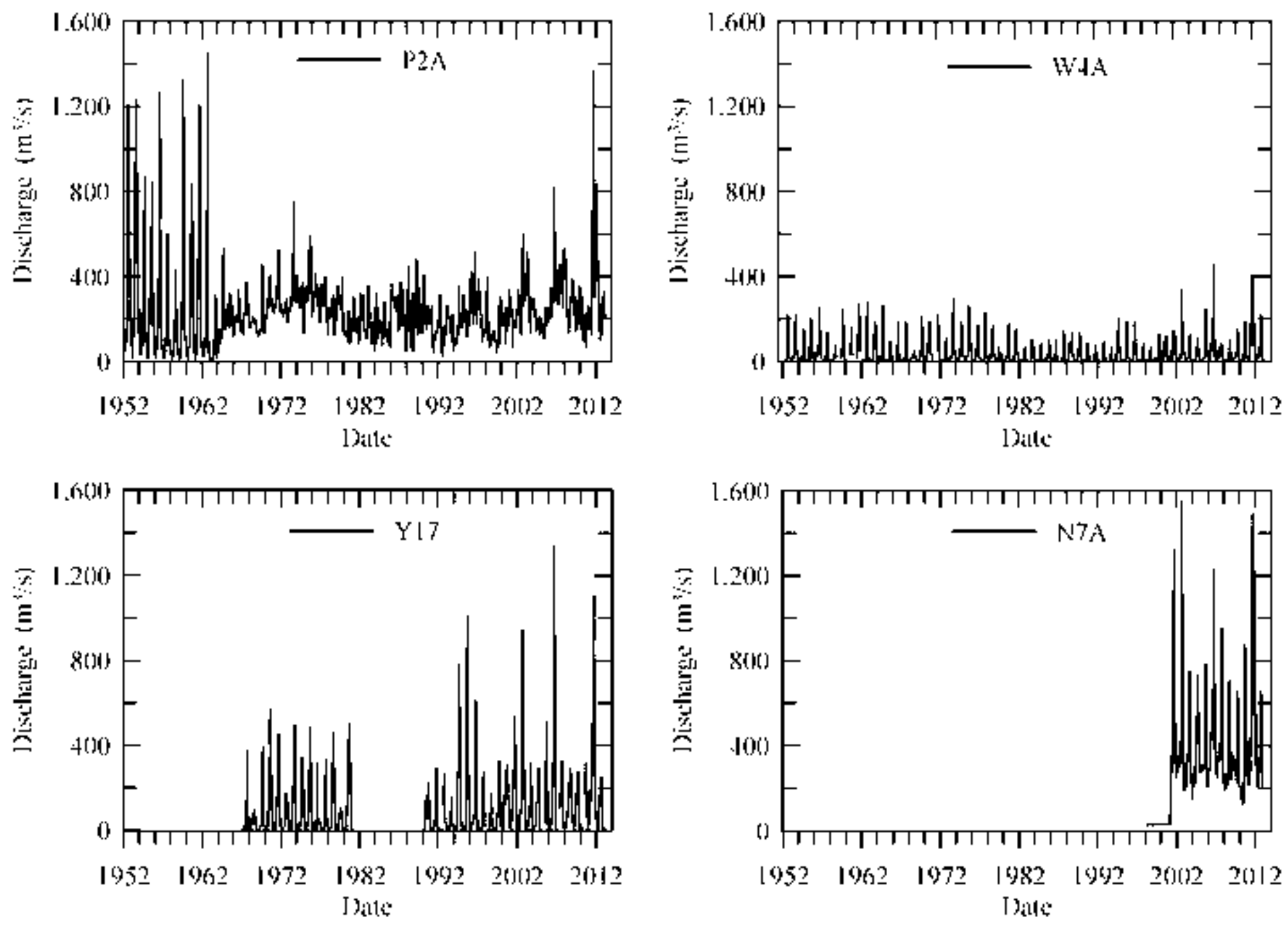


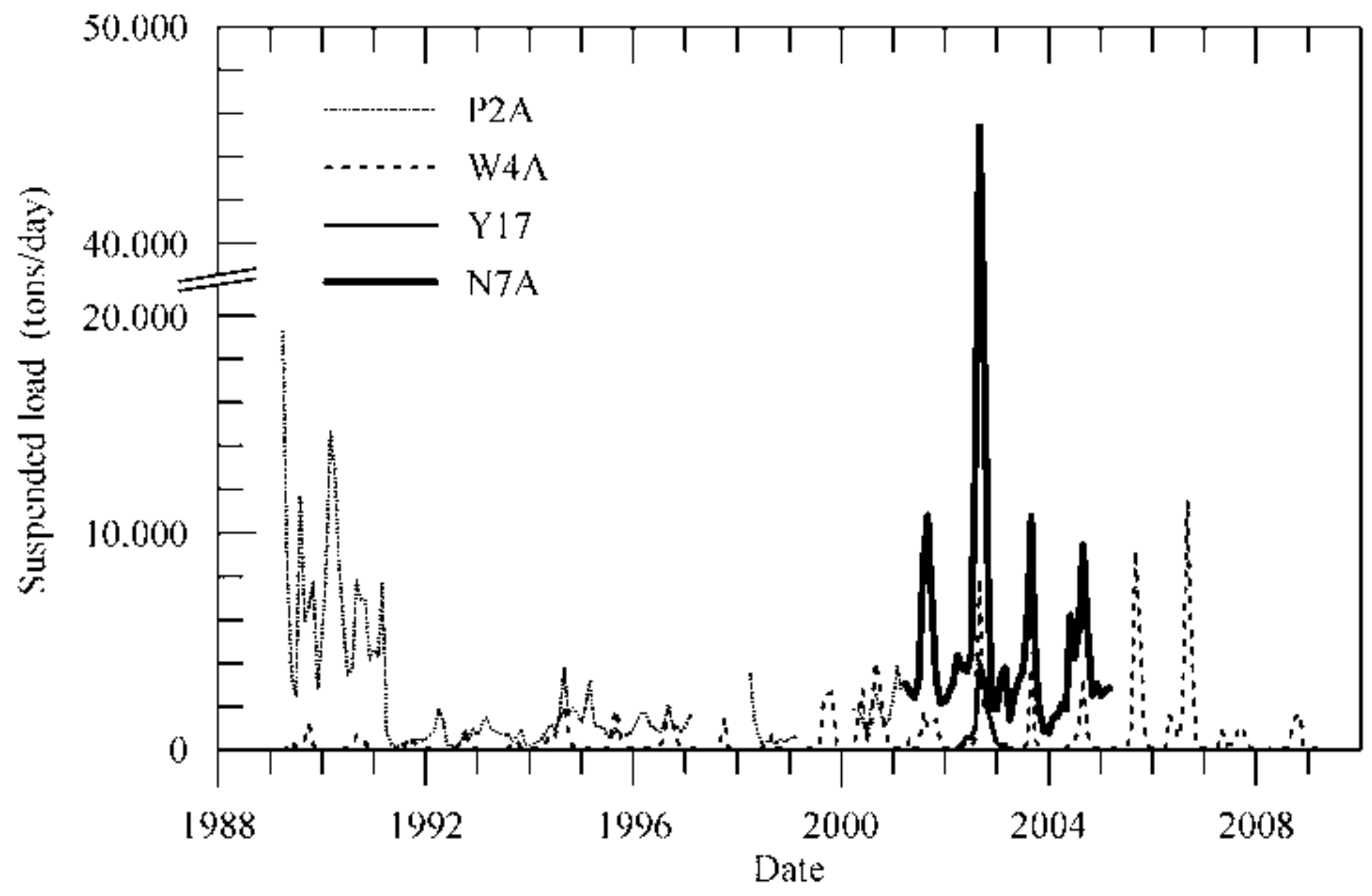




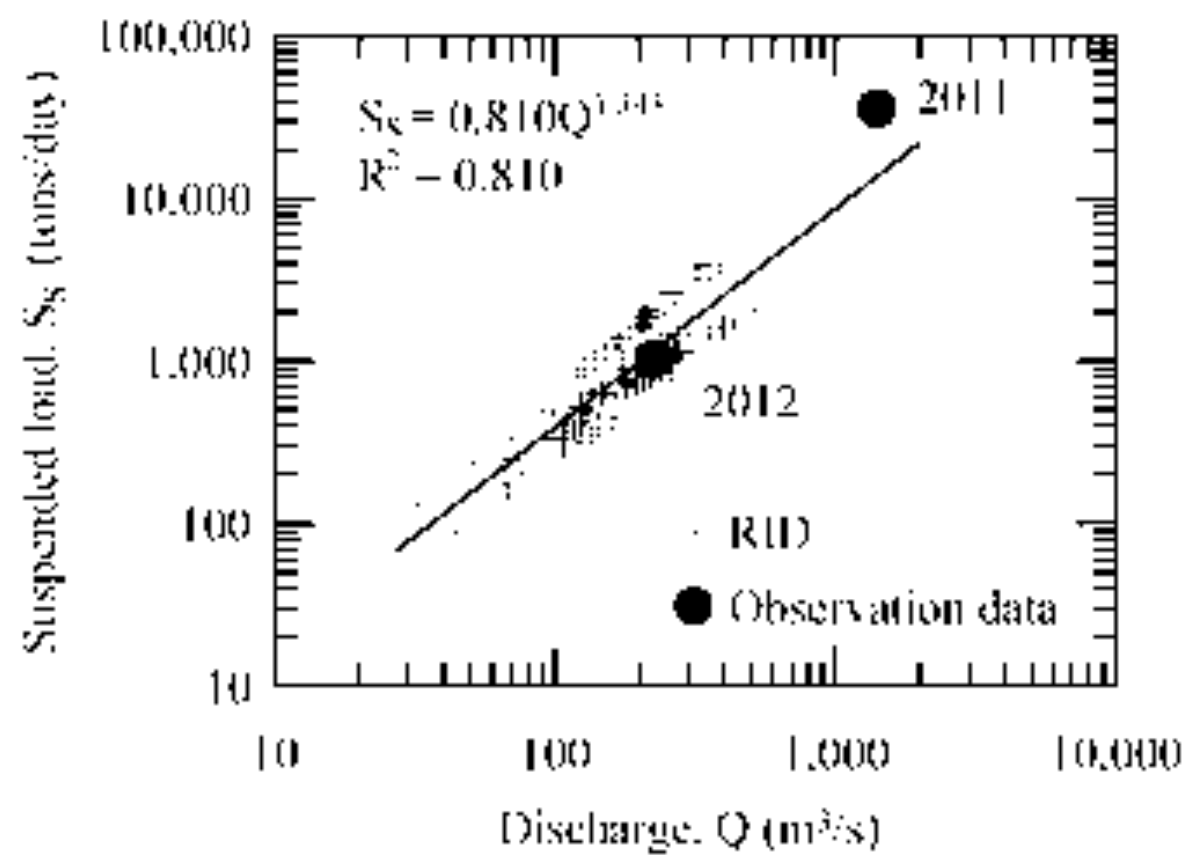

a) Station thex

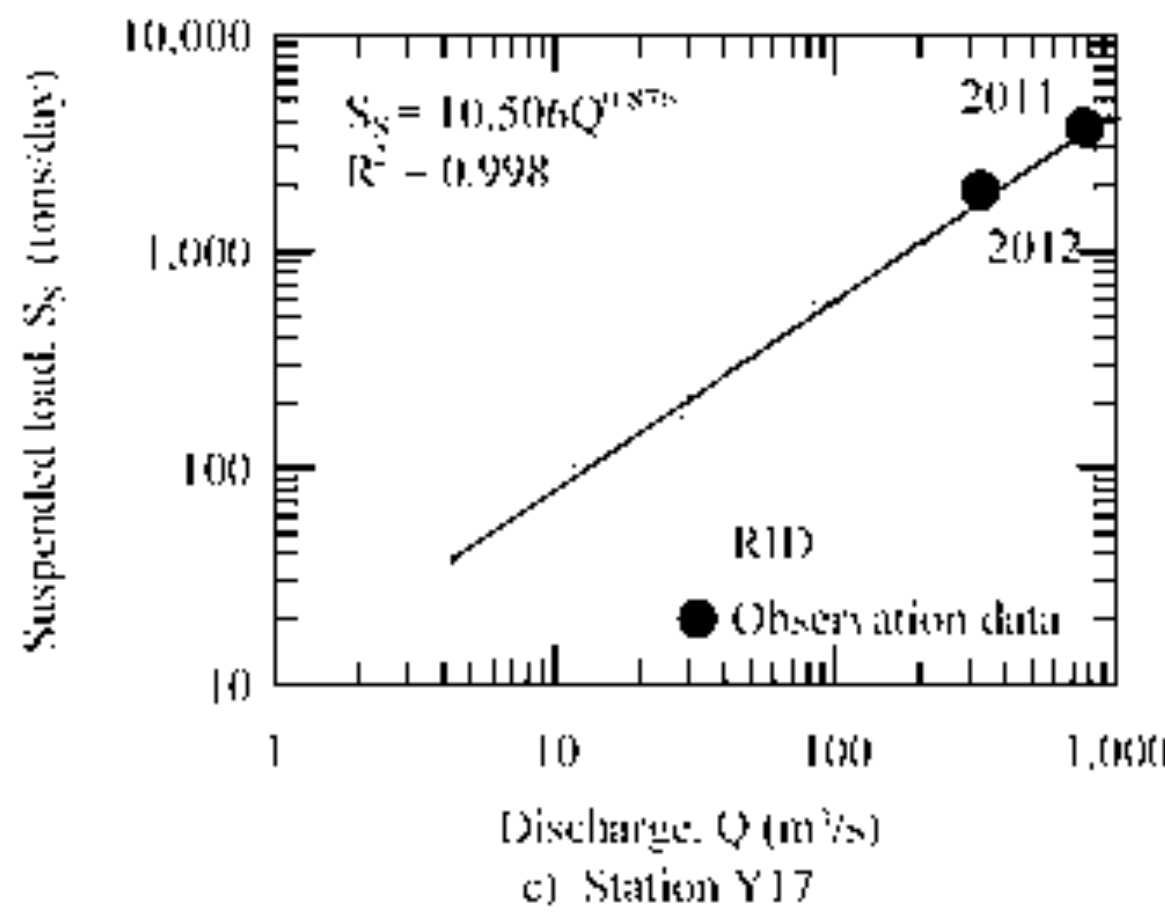

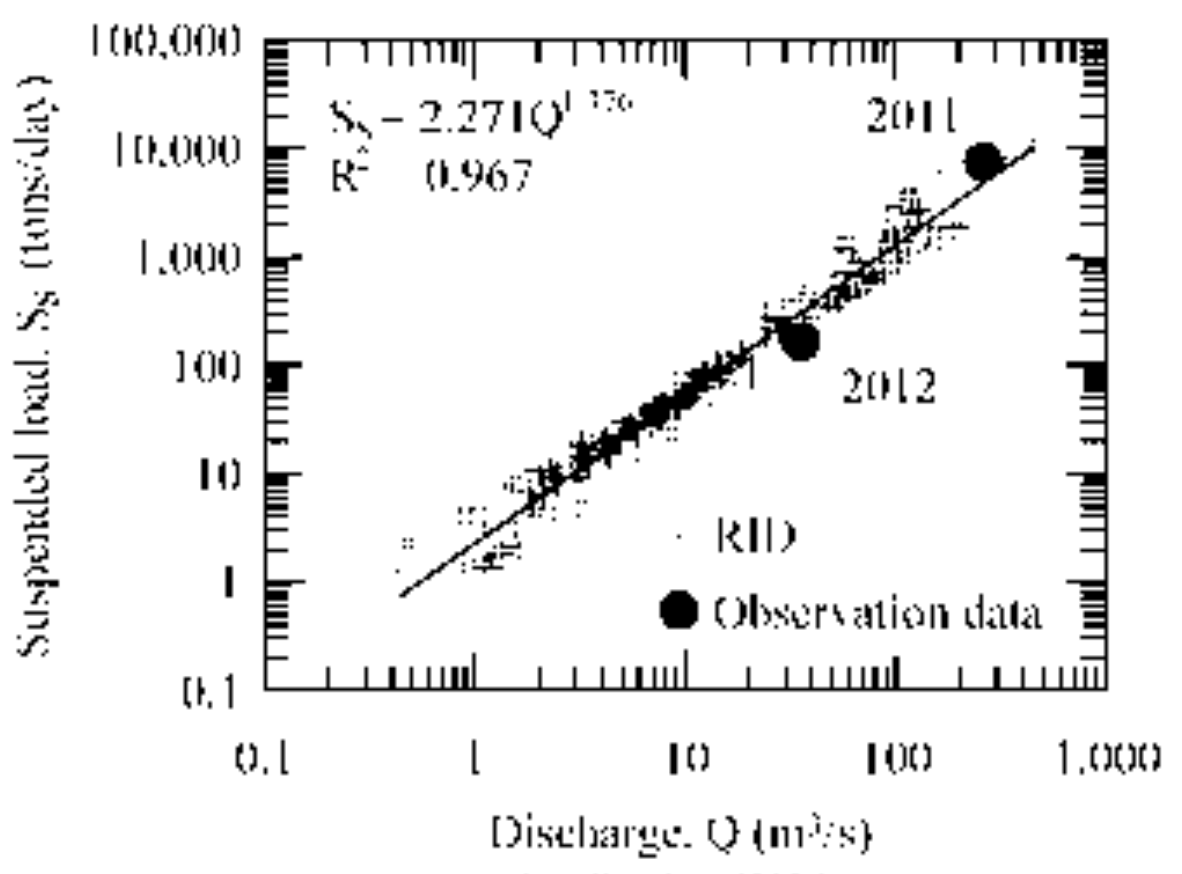

(1) Siation it 4 A

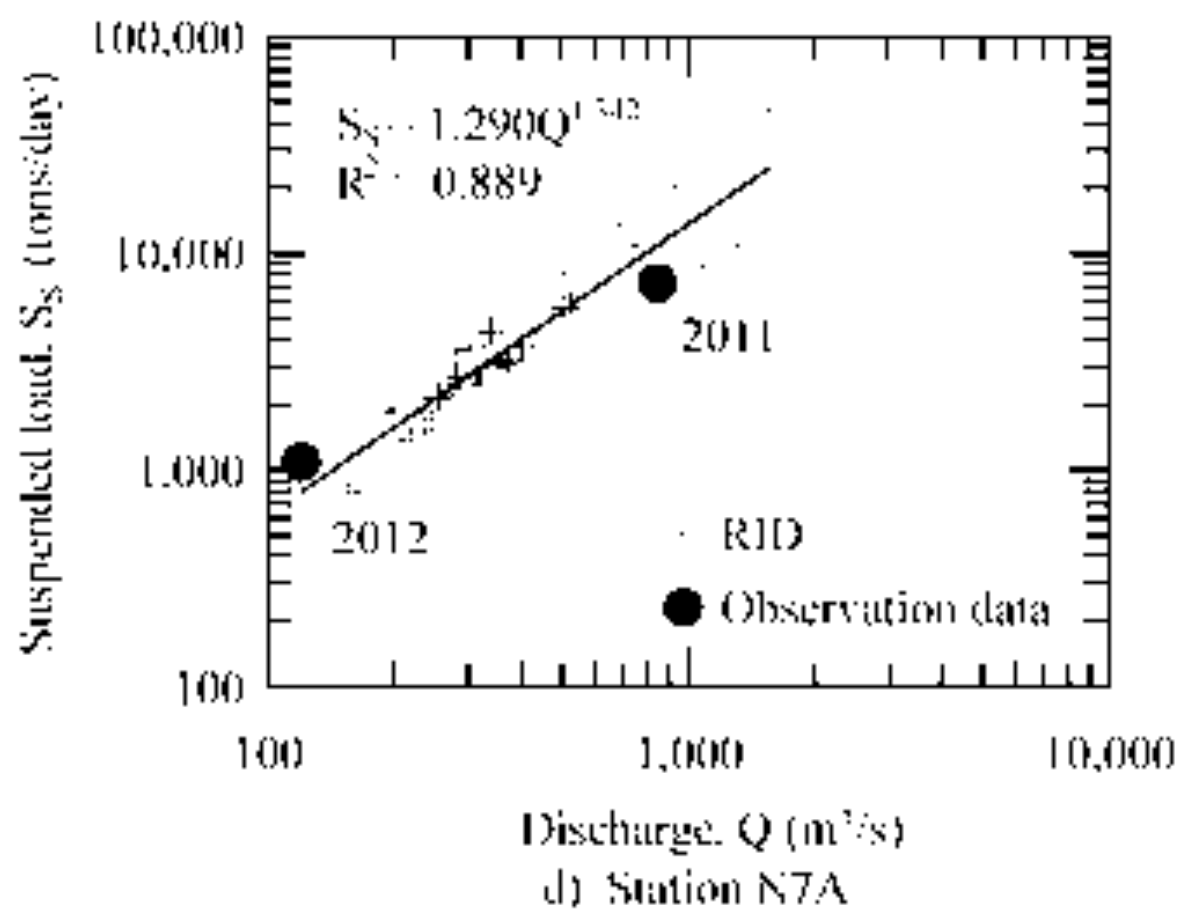




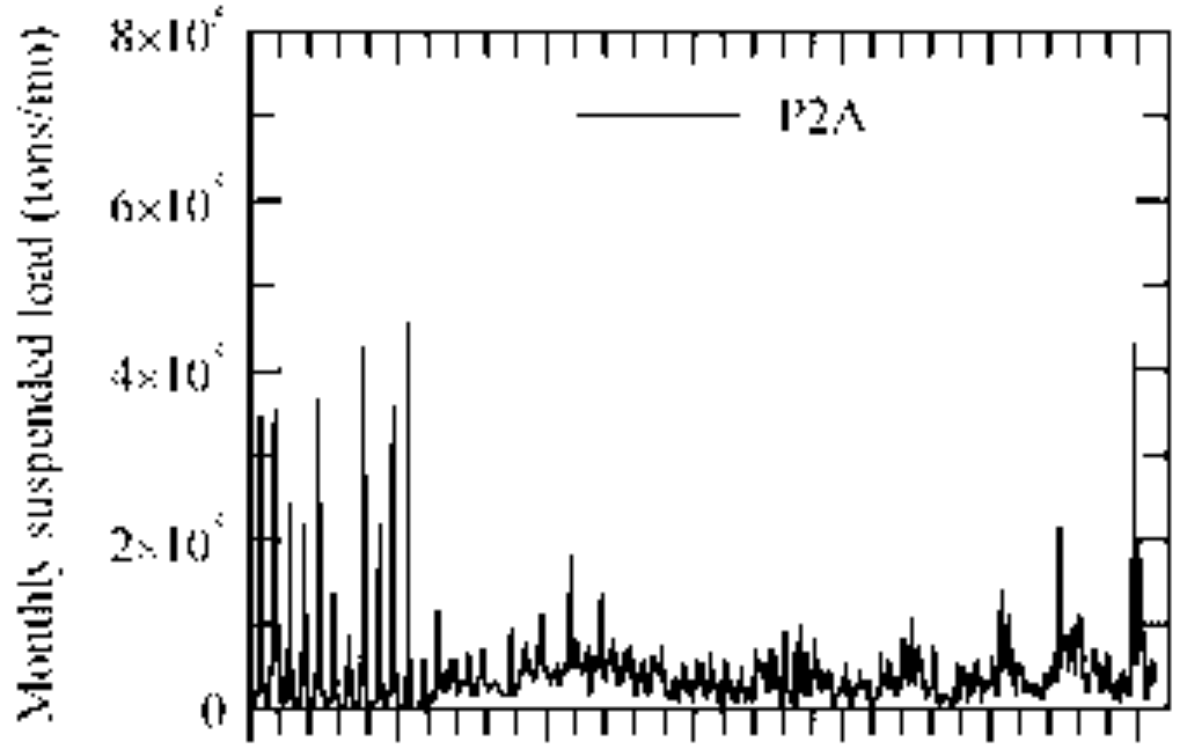

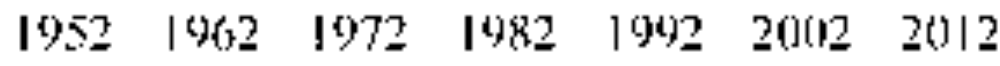
1)

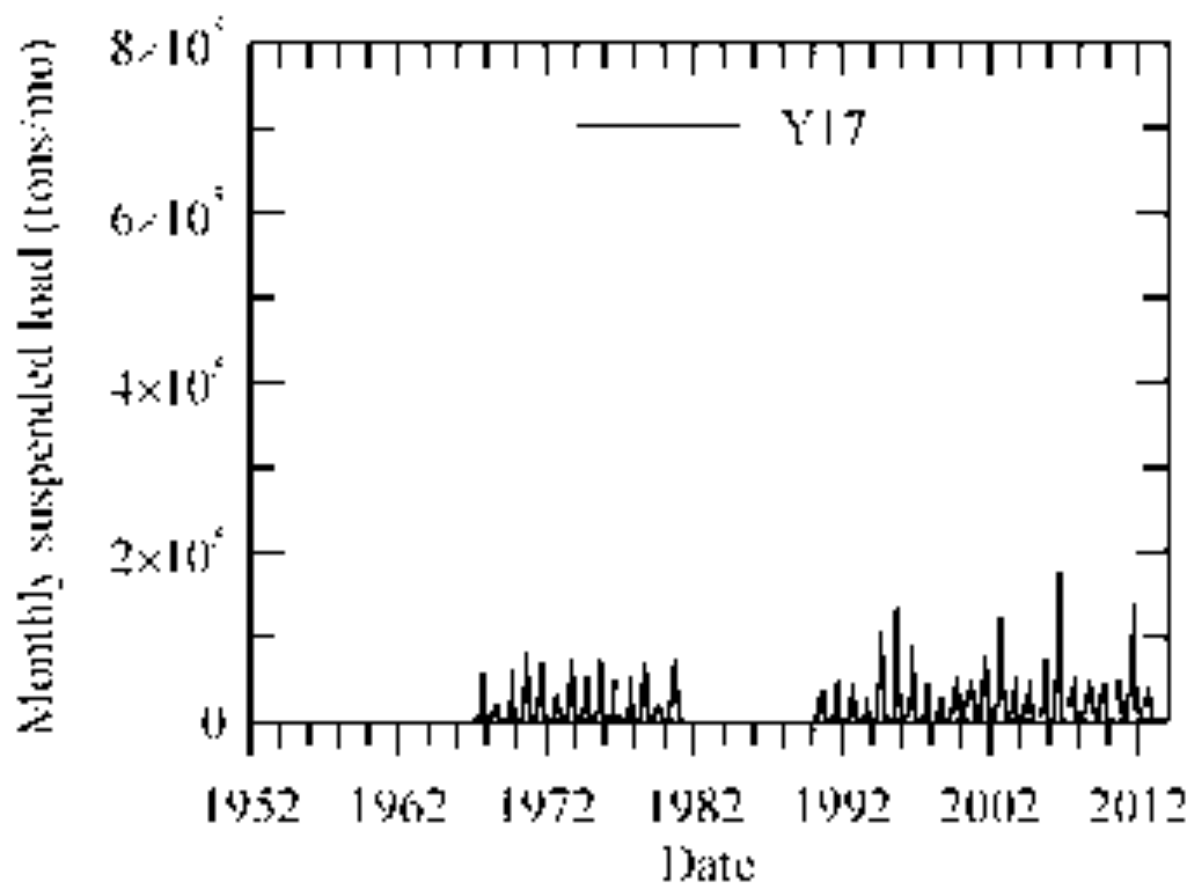

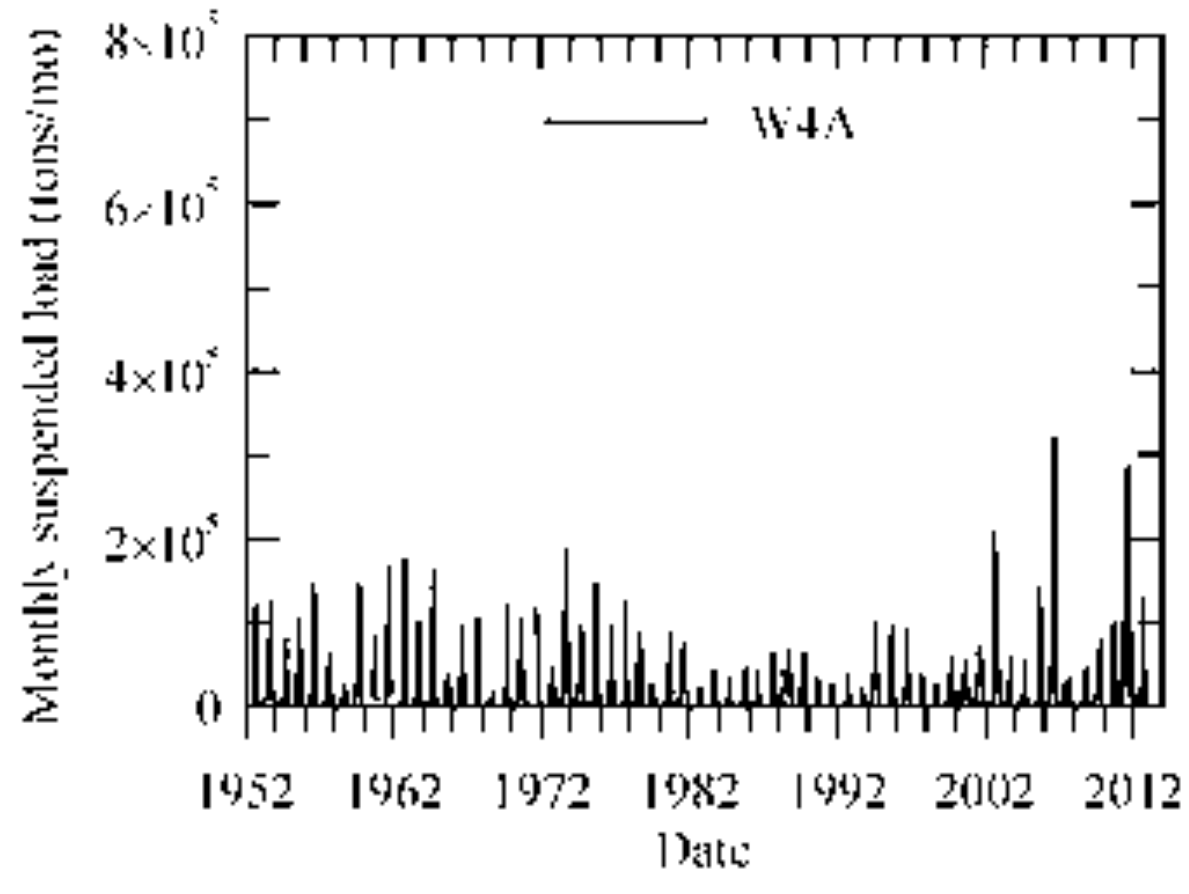

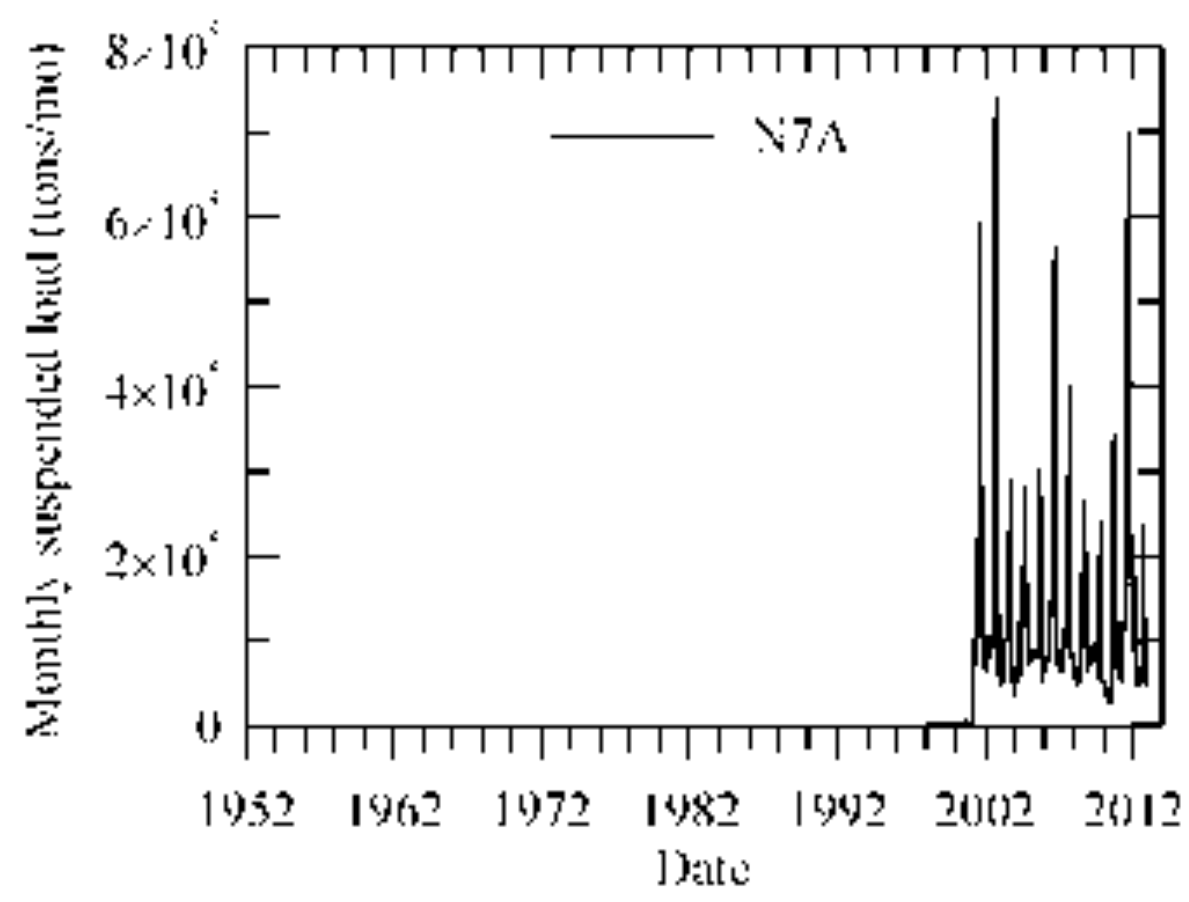




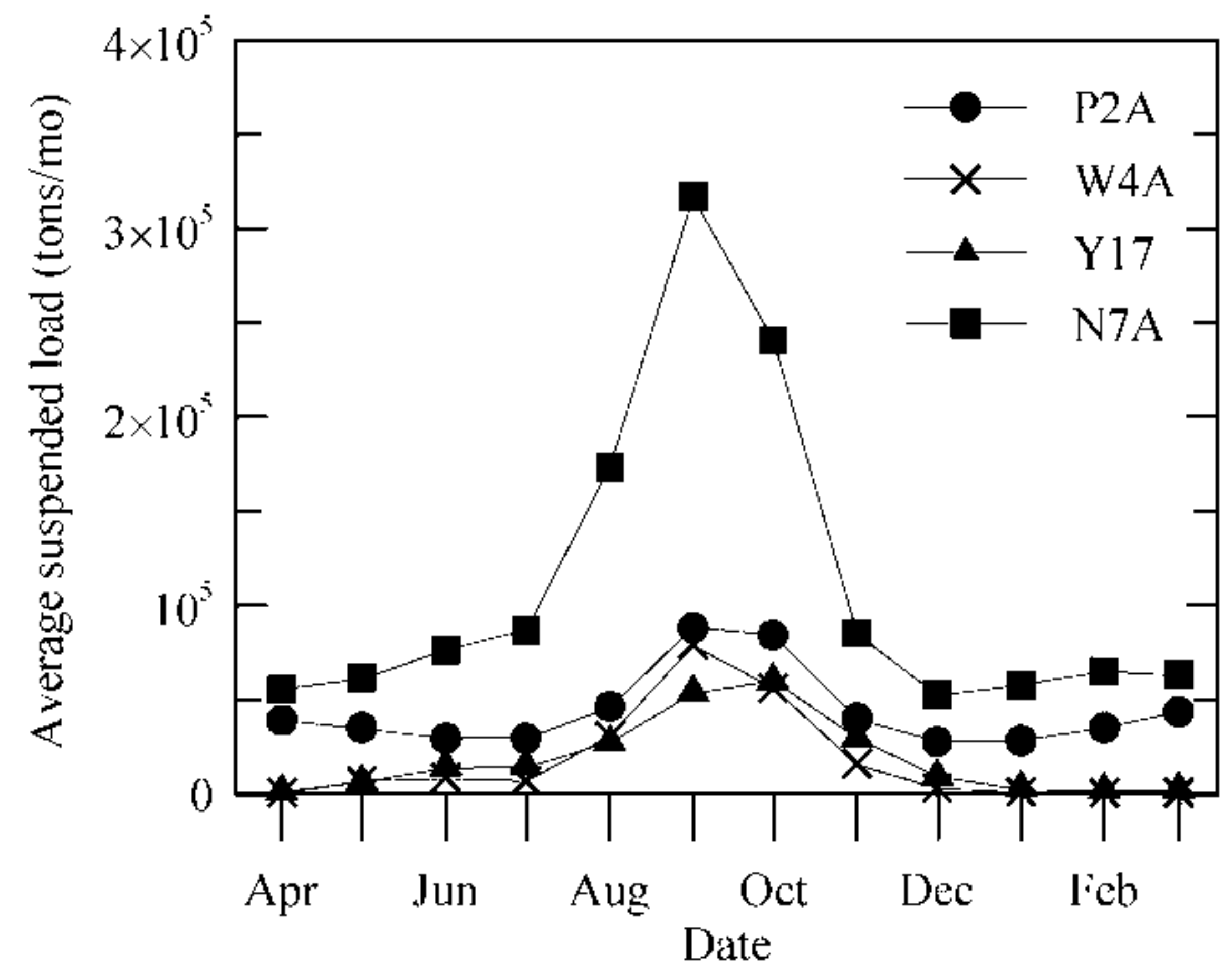

Fure 8 


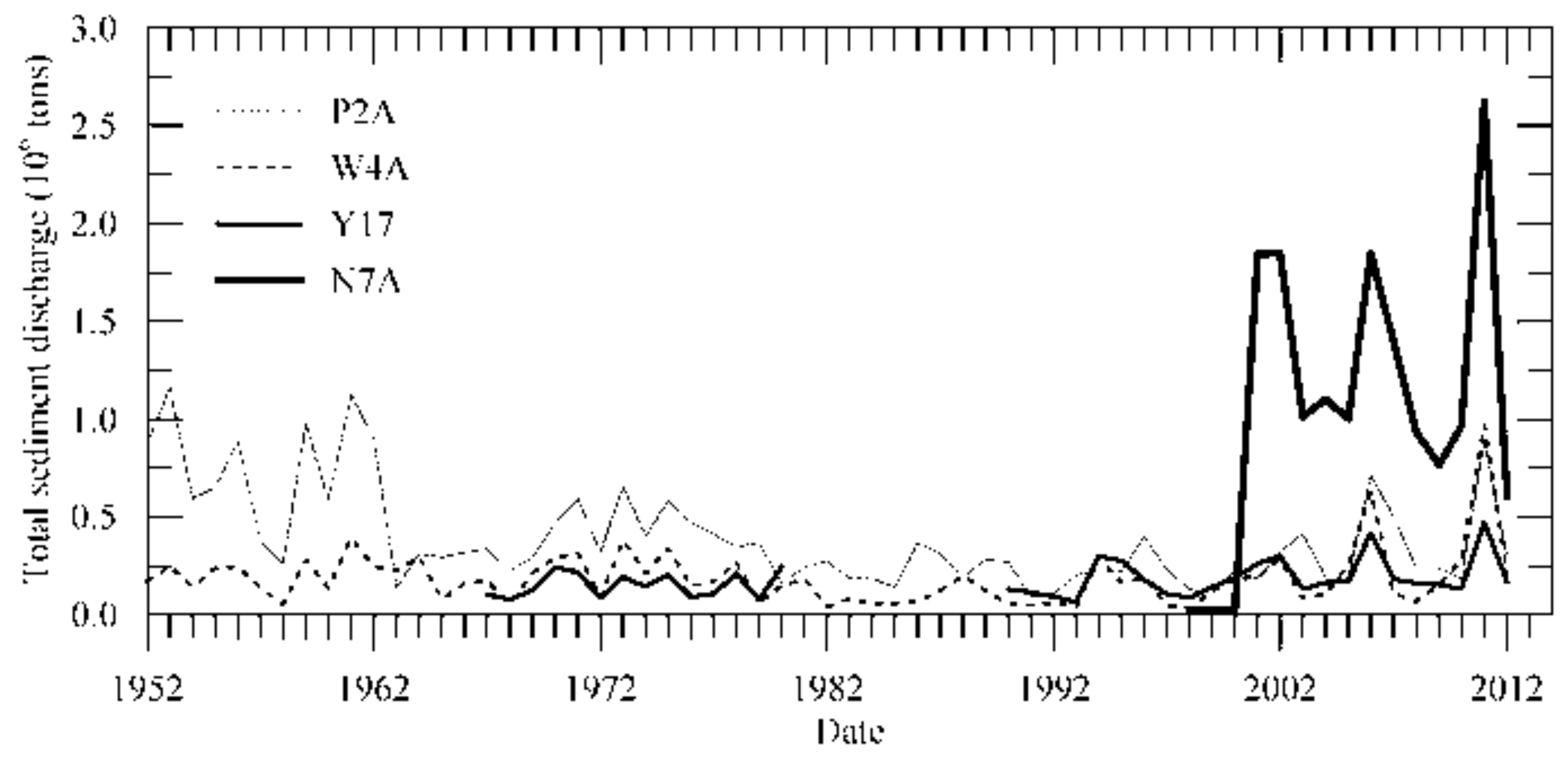




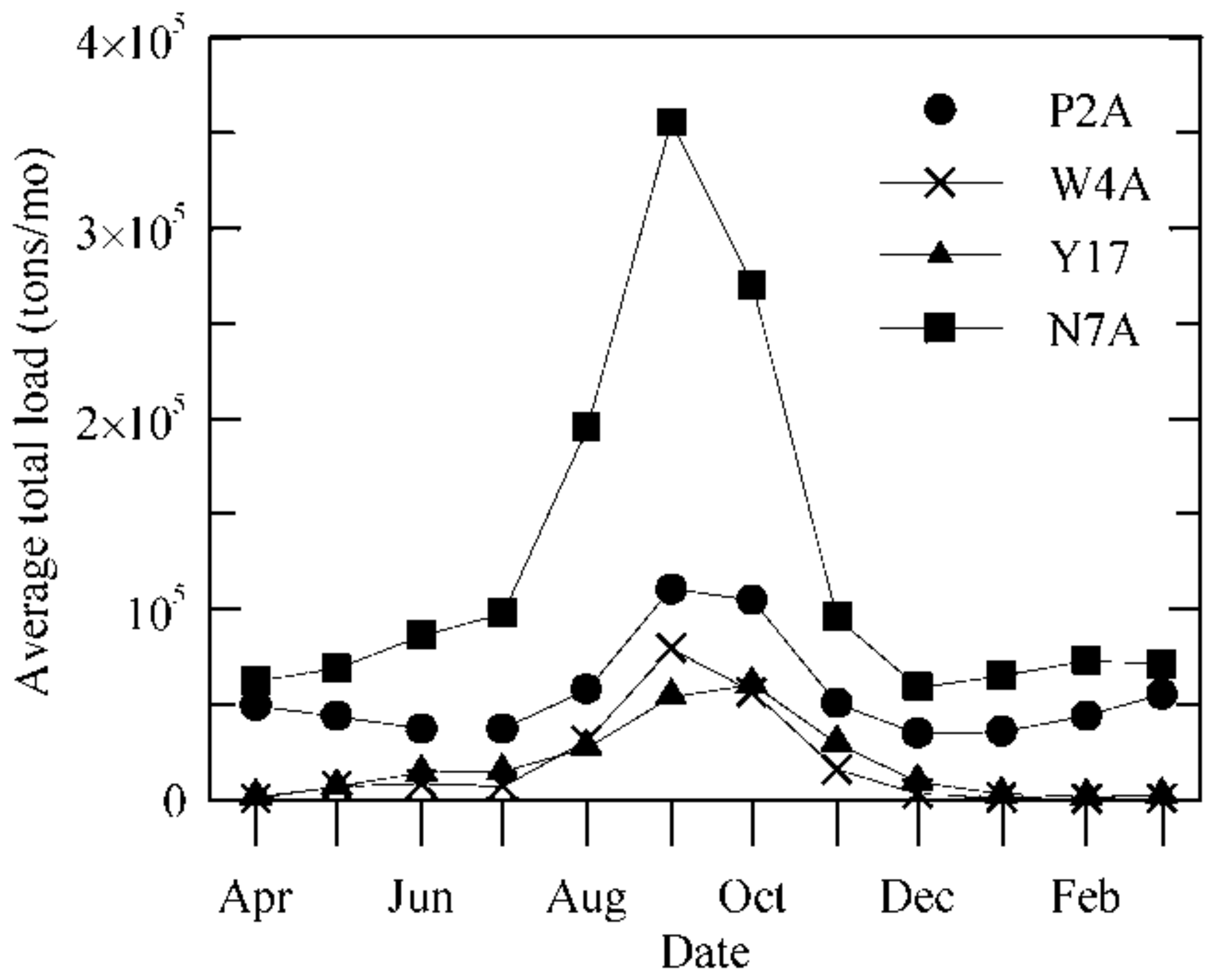

